\title{
The Comparative Morphology of the Genitalia of Insects
}

by

\section{ANNA GRACE NEWELL}

B. A. Smith College, 1900

M. A. Smith College, 1908

\section{THESIS}

Submitted in Partial Fulfillment of the Requirements for the Degree of

\section{DOCTOR OF PHILOSOPHY}

In Entomology

in the Graduate Schoo! of the University of Illinois 1916

Reprinted from the Annal; of the Entomological Society of America

Vol. XI, No. 2, June, 1918 



\subsection{6 $\mathrm{N} 44 \mathrm{c}$}

\section{BIOGRAPHY}

The candidate was born December 23, 1876, in Flint, Michigan, and most of the work covered in the grammar grades was done in that city. Preparation for college was received in the High School at Batavia, New York, and the following four years were spent at Smith College, from which the degree of B. A. was received in June, 1900.

In 1907 the candidate was appointed instructor in Zoology at Smith College and in 1916 was made Assistant Professor in the same subject. The intervening years between 1900 and 1907 were spent partly as a substitute at Smith College in the Zoology Department, partly at home, and in Europe for the year 1906-07, during which one semester was spent in the study of Zoology, at the University of Leipzig.

Work in Entomology was done at Cornell University, under Professor A. D. McGillivray, during the summer sessions of 1908 and 1909 , as well as for the year 1914-15 at the University of Illinois. The second minor subject, Ecology, was studied at the summer laboratory of the University of Montana in 1913, under Dr. C. C. Adams and under Professor V. E. Shelford, at the University of Chicago, in the summer quarter, 1914. 
Digitized by the Internet Archive in 2017 with funding from

University of Illinois Urbana-Champaign Alternates

https://archive.org/details/comparativemorph00newe_0 


\title{
THE COMPARATIVE MORPHOLOGY OF THE GENITALIA OF INSECTS.*
}

\author{
Anna Grace Newell, Ph. D.
}

I. INTRODUCTION.

1. Somites.

2. Theories and Investigators.

3. Posterior Somites.

4. Genitalia.

5. Cerci.

6. Acknowledgments.

II. Investigation.

1. General Principles.

2. Method of Preparation.

3. Discussion and Tables:
a. Thysanura.
b. Orthoptera.
c. Hemiptera.
d. Neuroptera.
e. Mecoptera.
f. Trichoptera.
g. Coleoptera.
h. Lepidoptera.
i. Diptera.
j. Hymenoptera.

III. Summary.
1. Somite Eight.
2. Somite Nine.
3. Somite Ten.
4. Somite Eleven.
5. General Statement.
6. Appendage I.
7. Appendages II and III.
8. Appendage IV.

IV. BIBLIOGRAPHY.

V. Explanation of Plates.

VI. Plates.

\section{INTRODUCTION.}

1. Somites. - The third and caudal region of those into which an insect is divided is called the abdomen. Here, for the most part, the segments of which it is composed show a simple and almost primitive structure. In the adult a typical segment, more properly designated a somite, consists of a dorsal chitinized portion or sclerite, called the tergum, and a ventral sclerite, or sternum. These are connected laterally by arthrodial membranes, conjunctiva or pleura, in each one of which is a spiracle. There are exceptions to this arrangement at both cephalic and caudal ends, with the greater complexity at the latter. No

* Contribution from the Entomological Laboratories of the University of Illinois, No. 51 . 
spiracles are ever present caudad of the eighth somite, and, in most cases, where the somites caudad of the seventh are retracted, spiracles are lacking in the eighth. Therefore it is evident that the adult abdomen always presents, to the eye at least, a far more simple composition than do the head and thorax. In reality, in many larvæ an abdominal somite is an entire ring without differentiation into tergite or sternite, an arrangement often seen in the lower thoracic somites, and a more nearly primitive one than that above mentioned.

The general shape of the abdomen, taken as a whole, also varies considerably. According to the best authorities, one ought to recognize the abdomen, systematically, from the number of its somites and from its appendages. The fact suggested above, that the caudal somites may be more or less, even entirely, concealed by retraction, is responsible for the numbering of abdominal somites which is based only upon the number of visible somites and has no justification in morphology. Disagreement upon this point is found, however, not only among the systematists, who formerly limited themselves to numbering the abdominal somites which were undoubtedly visible, but also among the morphologists. The latter differ in their results for various reasons, as follows: (1) Because of the loss of certain sclerites. (2) Because of differences in the point of view: $e . g$., some investigators begin to count at the cephalic, while others begin at the caudal end of the abdomen, and still others do not correlate closely dorsal and ventral sclerites. (3) Because, undoubtedly, of failure to observe the sclerites present in the caudal region, due in many cases to the lack of potash or other suitable reagents and methods for exposing chitinized parts.

2. TheOries AND Investigators.- - There follows at this point a list of prominent investigators together with the number of abdominal somites which they have believed were present in the adults of certain orders:

ORTHOPTERA.

1872 Chadima.................................... 11 abdominal somites

1876 Brunner von Wattenwyl. . . . . . . . . . . . . . . . . 9 abdominal somites

1882 Tarzioni-Tozzetti.............................. 11 abdominal somites

Coleoptera.

1894 Peytoureau (in Hydrophilus).

.8 abdominal somites

1894 Peytoureau (in Dytiscus)..

9 abdominal somites

1893 Kolbe (in lamellicornia)

9 abdominal somites

189318941896 Verhoeff.

10 abdominal somites

1903

Berlese (in Coleoptera in general)

11 abdominal somites 


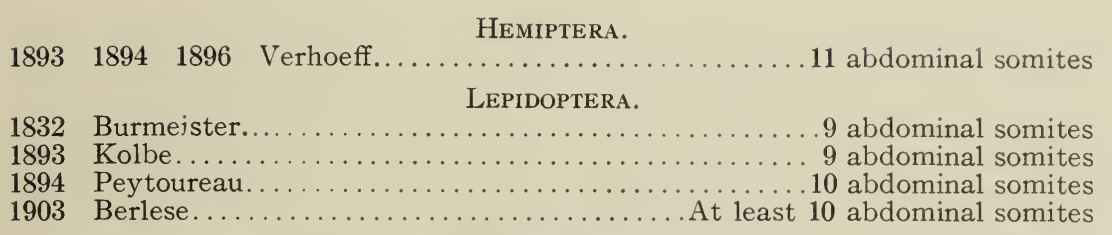

TRICHOPTERA.

1849-53 Lacaze-Duthiers, typical number in insects.......11 abdominal somites 18861888 Grassi, typical number in insects............10 abdominal somites

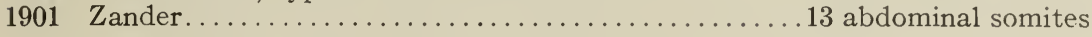

From investigations on Thysanura, according to Grassi, there are 10 abdominal somites besides "ein Afterstück, das allerdings nicht mehr als Segment aufzufassen ist;" according to C. Brunner von Wattenwyl, this is a terminal segment, welches aus den drei Afterklappen und den seitlich inserirten "Anhängseln (Cerci) gebildet wird."

Berlese concludes his discussion of the matter by saying that the entire number of abdominal somites varies from nine to eleven, except for the Collembola, which he considered aberrant, this reduction taking place from the lower to the higher orders, and at the caudal as well as at the cephalic end of the abdomen. He states emphatically that eleven is not exceeded, aside from the telson with its rudiments, found only in certain of the Thysanura and immature Orthoptera, and he therefore would consider eleven as the typical number.

Certain other investigators, represented mainly by Heymons, uphold the view that the primitive number of abdominal segments is twelve; the twelfth, just as much as the eleven cephalad of it, containing a cælomatic cavity. Heymons calls this twelfth somite the telson, and his evidence for it is found mainly in certain Thysanura, where he identifies it with a small sclerite, called by many the supra-anal plate, situated between the eleventh tergite and the anus. He also describes it in immature Acrididæ, Locustidæ, and Gryllidæ as a triangular plate separated from the eleventh tergite, to which it forms the apex, by a suture. In the adults of some Acrididæ this plate becomes totally fused with the eleventh tergite. In this case the terminal segment is commonly called the eleventh only, instead of the eleventh and twelfth, according to Heymons. Berlese gives another example of the twelfth tergite in Acrida turrita L., a form not studied by Heymons. (Plate VI, Figs. 1, 10,13 , and 17 t 12.) 
According to Haase, the eleventh is not an autonomous somite, and Verhœff agrees with him. Dewitz states that the eleventh somite is formed only by the doubling of the tenth, and he says that in Decticus this only occurs after hatching. Wheeler shows and labels eleven segments in all the figures in his well known embryological investigations.

3. Posterior Somites. - The first traces of segmentation are found very early in the germ-band of the insect, which becomes divided by transverse grooves into somites. This process, Heider maintains, even precedes gastrulation in Hydrophilus. This is not a primitive condition however. In the completely segmented germ-band, Korschelt and Heider state, there are ten abdominal somites in addition to the telson, and they give the following observations on the germ-bands of various forms, in proof of this statement: Heider, on the germband of Hydrophilus; Graber, on Lina, Stenobothrus, various Lepidoptera and Hylotoma; Wheeler, on Doryphora and Blatta; Cholodkovsky, on Blatta; and Carrière on Chalicodoma.

In looking over the plates belonging to all the articles referred to by Korschelt and Heider, in each of the above cases, one sees that in the large number of germ-bands figured the terminal abdominal somite is always numbered eleven, and that in no case is the term telson used, that being the name given by Heymons to the twelfth abdominal somite. Of course, morphologically, what these somites are labeled may seem immaterial, and fundamentally it is. However, there is no doubt that considerable confusion has arisen from Korschelt and Heider's statement in this regard. Many invariably take it that, according to these authors, the insect abdomen is typically composed of ten somites and no more. Others may understand that the telson mentioned is formed of the eleventh and twelfth somites fused. As one can see from the work of the investigators themselves, they agree in giving eleven as the typical number of abdominal somites in the germ-bands of the insects upon which they worked.

One of the difficulties in arriving at any conclusion from the foregoing is that so few investigators have traced structures from embryonic through larval to adult stages, and this same difficulty confronts us when we review the work done on the genital appendages. 
A marked deviation from the primitive condition is found in the lack, apparent, at least, of appendages on the adult abdominal somites. If one looks at the germ-band of an insect, however, one can see, soon after the appearance of the appendages of the head and thorax, anlages of a pair of appendages for each somite of the abdomen also. These rudiments are lateral, saclike swellings, usually pointing backward, and generally considered as serially homologous with the thoracic legs, as also with the appendages of the head.

The first account of embryonic limb rudiments on the first abdominal somite of Gryllotalpa, was written by Rathke in 1844 , and, later, on all the abdominal somites, by many others. As we mean by primitive, in insects, that which shows their close relationship to, and probable descent from, a myriapodlike form consisting of several, successive, similar somites, each having a pair of appendages, we are interested to look in the adult for traces of the embryonic condition described above.

4. Genitalia.- - There is, at the caudal end of the abdomen of every insect, a group of appendages having to do, more or less directly, with the function of reproduction. Three pairs of these appendages taken together are called, in a general way, by German authors, "Geschlechtsanhänge"; by English and American ones, "genital appendages," "genitalia," or "gonapophyses," the latter, a term introduced by Huxley in connection with the Crustacea, and used by many others to indicate part or all of these structures, in one or both sexes. They have also been given, individually, names differing from one another in, and characteristic of, each order, so that in some cases only a systematist of the group concerned could follow a description using them. These three pairs of appendages have been attributed to the three somites cephalad of the terminal or anal somite, which, as explained in the foregoing, is considered the eleventh by some and the tenth by others.

It would seem natural to homologize these appendages with the anlages of legs found respectively on the same somites of the embryonic germ-band, but there are at least two opposed views on this question. Lacaze-Duthiers, who published papers on the subject in 1849-52, did not so consider them, but regarded them as modified ventral sclerites of their respective urites, the latter being the name by which this author, followed in this respect by Berlese and others, called the abdominal somites. 
Haase, much later, also stated that the gonapophyses were not true appendages, but, to translate, "integumental structures of a somewhat higher order than styles," meaning those styles which are inserted at the bases of the legs, in the coxæ of some Myriapods and Thysanura. Grassi in 1889 held a similar view. According to Wheeler, all these investigators based their conclusions solely upon comparative anatomical data. The following investigators, however, have regarded these appendages, genitalia or gonapophyses, as homologous with the true, so-called "ambulatory," "segmental," or "pedal" extremities, although they have differed a good deal in the details of their explanations: Weismann in 1866; Kræpelin in 1872; Kowalevsky in 1873; Dewitz in 1875; Huxley in 1877; Cholodkovsky in 1891; and Wheeler in 1893.

Korschelt and Heider state their point of view as follows: "We are here led to ask to what extent the external genital appendages, the so-called gonapophyses, are to be traced back to limb rudiments. The researches of Kræpelin and Dewitz have revealed that the ovipositors of the Hymenoptera and the Locustidæ, and the corresponding genital appendages of the male in these forms, are derived from the imaginal discs of the eighth and ninth abdominal somites, which, when they first appear in the larva, closely resemble the imaginal discs of the larva of Corethra, which yield the thoracic limbs." (p. 371.) Bütschli and others have therefore attempted to refer the gonapophyses of these forms to true, abdominal limb-rudiments. "In support of this assumption, we might point out," continue Korschelt and Heider, "that these imaginal discs develop from the abdominal rudiments present in the embryo." "It should, however, be mentioned," they assert, "that Haase, following Uljanin, has recently opposed this view, although, as it appears to us, with insufficient reason, maintaining that the gonapophyses should be regarded merely as secondarily acquired, external appendages."

Heymons is one of the strongest opponents of a homology between the genital appendages and the anlages of the segmental ambulatory ones of the embryo and the appendages of an ancestral form. He states in a résumé published in 1899 that after embryological investigations on a great number of species of Locustidæ, Gryllidæ, and Hemiptera, he has come to the conclusion that it is a fundamental principle, in the study of 
insect embryology, that there is present no genetic relationship between the embryonal anlages of the ambulatory appendages and the gonapophyses.

The entirely different results obtained by Wheeler, from his embryological work on Xiphidium, Heymons attributes to the fact of an unusually early origin of the genitalia in Xiphidium and other Locustidæ, even as early as the embryonal period before the atrophy of the anlages of the segmental appendages. Also, in addition to this fact, Heymons lays emphasis upon the very small size of the sternites in Locustidæ, which would very easily lead one to confuse the embryonic limb-rudiments and the developing genitalia or gonapophyses; while in other forms, he states, the sternites are much larger. In fact, Heymons asserts, from his investigations on Lepisma saccharina and certain Hemiptera, that the sexual appendages do not originate even in the same parts of the sternites where the above-mentioned anlages of segmental appendages are found. It seems unbelievable that an investigator who has had as much experience as Wheeler in the examination of insect embryos should have made the mistake attributed to him by Heymons.

The anlages of segmental appendages on the middle and cephalic, as well as on the caudal somites, degenerate during the embryonic stages, and some authors, Goosens and Knatz, for example, have thought that, for this reason, the prolegs of caterpillars first develop during larval life. To quote again from Korschelt and Heider: "We should here have to suppose, as Graber also has pointed out, an embryonic rudiment remaining for a considerable time in a dormant condition. On the whole, the embryonal data seem to support the view of Balfour which Cholodkovsky adopted, and to which Graber was inclined, that the abdominal appendages of the Lepidoptera and Hymenoptera are to be regarded as true limbs. We have already had several examples, in the Crustacea, of the disappearance and redevelopment of a limb out of a rudiment which has meanwhile been latent (Mandibular palp of the Decapod larva, Korschelt and Heider, Vol. II, p. 312; maxillipedes of the Stomatopoda, Vol. II, p. 300.) A similar example is afforded among the insects by the thoracic limbs of many Hymenoptera," and most Diptera for that matter. "These appear as rudiments in the embryo, disappear later, and reappear in the imago." 
In the above-mentioned résumé of 1899 Heymons takes up, point by point, Verhœff's work on Coleoptera and Hemiptera, as well as his papers on Tracheates and Myriapods in general, all published between 1892 and 1898. From the results of his review of these investigations Heymons concludes that there is little support for Verhœff's opinions. The latter include the homology of the styles which are attached to the coxæ of the mesothoracic and metathoracic legs of Machilis, as well as to certain abdominal somites of other Thysanura. According to Heymons, Verhœff compares the style-bearing sclerites, which he considers laterad of, and fused with, the true abdominal sternites, with flattened out coxæ, and that rightly, according to Heymons; but, going further caudad, Verhœff also homologizes the median genital appendages with the distal segments of the legs, and the lateral gonapophyses with the coxæ of these legs, therefore regarding the origin of two pairs of genitalia from one pair of ambulatory appendages belonging to one somite, instead of from two pairs belonging to two successive somites, or, to put it from Heymon's point of view, from at least four isolated evaginations having no connection with the anlages of the segmental appendages found in the embryo.

One objection which may be made to Heymons's theory, on general morphological grounds, is found in certain of his conclusions which he himself states as follows: "Heymons zufolge, sind die Geschlechtsanhänge männlicher und weiblicher Insekten nur als Hypodermisfortsätze zu betrachten," and "Die Geschlechtsanhänge sind, nach der Ansicht von Haase, Peytoreau, Heymons, u. a. erst innerhalb der Klasse der Insekten erworben." With but few exceptions we find that, in tracing the morphological history of almost any organs we may mention, more or less important and well developed in a group of animals, they have not recently "sprung into being" as it were. Nature is not in the habit, to put it differently, and perhaps in a trite, old-fashioned manner, of building structures out of "etwas Neues." A glance at the history of almost any vertebrate structure will reveal an example of this fundamental principle.

Wheeler realized the necessity of tracing organs not only in the embryonic stages, but also on through later ones. In his paper on Xiphidium he says that the embryonic history of the gonapophyses could be "continuously traced," since there is no flexure of the abdomen in that embryo as exists in so many other 
forms to obscure the ventral view of the somites. After the time of hatching, Wheeler calls attention to the fact that Dewitz, in 1875, traced the development of the ovipositor in another locustid, Locusta viridissima, so that we now have the complete history of that organ, or set of organs. Wheeler concluded that part of his account as follows: "While there can be no doubt about the appendages of the eighth and ninth segments which go to form the two outer sheaths of the ovipositor or sting, the development of the innermost blades is by no means so satisfactory. But whether this pair is only a portion of the ninth pair of appendages as most authors claim, or represents the tenth pair as I maintain, the main question at issue is in no wise affected; for it still remains true that the ovipositor consists of two or three pairs of modified ambulatory limbs." In the male Xiphidium embryo, it is claimed by Wheeler that the pair of appendages on the ninth somite persists, to form the definitive styli, those of the eighth and tenth somites disappearing very early. To quote again, "The continuity of the styli"-meaning here male genitalia - "with the embryonic appendages was quite as satisfactorily observed as the continuity of the ovipositor blades." He also says of the investigations of others, "Cholodkovsky has made an exactly similar observation on Blatta." The styli, therefore, in the male "are the homologues of the second pair of gonapophyses" in the female. "Haase must, therefore, have gone astray in seeking to homologize the styli" in the male, "with the styloid processes or "Griffel", above-mentioned in this paper as those styles attached to the coxæ of certain of the abdominal somites of some Thysanura, "for the styli," concludes Wheeler on the male Xiphidium, "are modified ambulatory appendages."

5. CERCI.-One more pair of appendages, namely, the cerci, should properly be included under the term genitalia, making the total number four pairs. The cerci, often tactile in function when present, are frequently described as attached to the terminal or anal somite. That different investigators have not meant the same thing, morphologically, by cerci, is undoubtedly true. Some regard them, not as appendages, but as prolongations of pleurites, $i$. e., of epimerites and episternites. Berlese explains this point of view, which he apparently takes. He says that there may be cerci on the tenth somite, as also on the ninth, the presence of the one generally excluding that of the other, 
although he would not lay this down as a fundamental principle. He gives Notonecta as an example of a case where he maintains that there is one pair of cerci on the eleventh somite, another pair on the ninth, and on somites cephalad of these he thinks there may be rudiments of others. His classification of cerci is as follows: the ones found on the eleventh somite, he calls acrocerci, or cerci; those on the tenth, mesocerci; and those on the ninth, procerci. The views of other authors are few in number, and have many points in common. Haase considers them as feeler-like appendages of the "Analstück"; Verhœff, true, segmental appendages of the tenth abdominal somite; Peytoureau, dorsal appendages of the tenth abdominal somite which may be compared, he thinks, with wings in their method of development.

Heymons and Wheeler in Orthoptera, and Heymons in regard to Dermaptera, Ephemerida, Odonata, and Thysanura agree that cerci are true appendages of the eleventh abdominal somite.

All of the foregoing opinions except Heymons's may be grouped together in that all their authors agree that the cerci are appendages, of one kind or another, belonging to the terminal abdominal somite. Heymons always regards the terminal anal somite as the telson, or twelfth abdominal somite, so would regard the cerci as appendages of the eleventh, or pre-anal somite. Verhøff lays great stress on the fact that the cerci must be segmented to be true cerci, comparing their segmentation with that of the thoracic legs. Haase and Heymons maintain that there is no relationship between the segments of these two structures as such, but rather a far-reaching, "weitgehende," according to Heymons-parallel between the cerci and the antennæ, not only in their present form, but in their ontogeny. It is certainly true that the cerci, generally speaking, bear a superficial resemblance to the antennæ, but they may also assume, physiologically, entirely different roles. Thus, for example, they may be purely sensory, but they may also be modified as accessory copulatory organs.

Cholodkovsky was the first, in 1891, to uphold the fact that the cerci were morphologically true pedal extremities, and it is the one place where Heymons can agree with him, as well as with Wheeler and others, that a pair of appendages which may properly be included under the genitalia has its origin in the 
anlages of the appendages of an embryonic somite. In fact, Heymons has called the cerci "modifizierte Extremitäten," and he states very emphatically that the cerci are homologues of the above-mentioned styles of some Thysanura, just as those styles themselves are descended from ancestral abdominal appendages.

6. ACKNowledgments.- - It is with the foregoing points of theoretical importance in mind that the following investigation is presented. At this point it would seem fitting to state that the investigation was begun at the suggestion of Dr. Alex. D. MacGillivray, of the Department of Entomology, University of Illinois, and I wish to express my gratitude to him for that and for countless timely suggestions and criticisms. I am indebted to Professor S. A. Forbes for many courtesies and for the use of material from the Illinois State Laboratory of Natural History, and also to the staff of that institution. I also desire to thank Dr. Harris H. Wilder, of the Department of Zoology of Smith College, for many important suggestions and criticisms. Dr. H. S. Pratt, of the Department of Zoology of Haverford College, very kindly collected for me specimens of Mantis sp. from a colony introduced on nursery stock, near Haverford, and I would at this point express to him my thanks. For considerable mechanical help with the drawings and their arrangement in the plates, I am very grateful to Miss N. B. Lewis, of Smith College.

7. MATERIAL.-The records upon which we must rely in determining the origin of the genitalia are the anatomy of generalized adult forms, a comparison of these with more specialized species and earlier developmental stages. Therefore, this paper consists of a comparative study of the caudal segments and appendages of adults of the following species: Lepisma saccharina and Machilis sp. of the Thysanura; Periplaneta orientalis, Melanoplus differentialis, Dissosteira carolina, Xiphidium ensiferum and Gryllus pennsylvanicus of the Orthoptera; Tibicen septemdecim, Notonecta undulata, Benacus griseus, Corixa sp., Anasa tristis and Euschistus variolarius of the Hemiptera; Corydalis cornuta of the Neuroptera; Panorpa lugubris of the Mecoptera; Nerophilus californicus of the Trichoptera; Harpalus caliginosus, Cybister fimbriolatus, Hydrophilus triangularis and Doryphora decemlineata of the Coleoptera; Hepialus humuli, Prionoxystus robinice, Agrotis ypsilon, Anosia plexippus and Phlegethontius sexta of the Lepidoptera; 
Tipula abdominalis, Tabanus sulcifrons and Calliphora viridescens of the Diptera; and of the Hymenoptera, Dolerus unicolor and Vespa maculata.

\section{INVESTIGATION.}

General Principles.-Before taking up any anatomical description or comparison of the foregoing forms, a number of preliminary points should be mentioned.

The distal pair of appendages, as has before been noted, is the cerci, and in the majority of cases in adult insects where these are present they have so changed their position as to be dorso-lateral, or even quite dorsal. As many of the succeeding pairs of appendages as are present are, as a rule, still in a ventral position, and may project beyond the caudal end of the abdomen. Therefore, it will usually seem convenient to begin descriptions of the genitalia by describing the cerci first.

Of the two sexes the female is the more generalized. A good example of this point is seen in the female cockroach where all four pairs of genital appendages are present, almost in their primitive position so far as showing their points of attachment to their respective segments is concerned, and where the total number of segments found in adult insects is also present. The saw-fly is another striking example of the generalized female. These are both examples in primitive families of insects, but on the other hand, in certain specialized groups which do not sting, and which, laying their eggs merely on the flat surfaces of leaves or stems, lack ovipositors, the caudal end of the abdomen presents a most generalized condition, the appendages in such cases being, "specialized by reduction." The genital and anal openings in these insects may be easily seen in a caudal view, the former between the ninth and tenth sternites under the edge of the ninth, and the anus in its usual position between the distal tergite and its corresponding sternite. These openings and whatever rudimentary appendages there may be present are enclosed within a cavity formed by the invagination of the segments beyond and including the eighth. From this sac-like invagination, the appendages may be protruded. When ovipositors and stings are present in specialized forms, these too are often concealed, or at least partially so, in pocket-like cavities similar to the one described above, except that they are usually somewhat longer. 
The genital opening of the male is connected with the tenth sternite more closely than with any other, as Berlese states. However, certainly in the adult insect, it is also situated at the distal end of an intromittent organ, which is, in many cases when entirely protruded, nearly as long as the abdomen, and thus the ejaculatory duct is also prolonged to an equally great length, therefore, bringing the external opening itself to a point without any relation to the abdominal sclerites.

Somewhat similar cases occur in such females as possess long ovipositors. However, the distal opening of the vagina itself is seldom situated far beyond the bases of the ovipositors. When the eggs leave this opening, they follow along well-marked grooves on the inner surfaces of the ovipositors into the ground, stem, or other object in which they are to be laid. This same mechanism may exist for the exit of poisonous fluids exuded at the bases of stings, or, as is often the case, through excurrent ducts leading from the glands to an external opening, or paired openings, also situated at the bases of the stings.

In those insects which have their caudal segments and genitalia retracted, the caudal end of the body has a smoothly rounded contour, or it may even be pointed. Excellent examples of such cases are seen in the Diptera and Hymenoptera. In these, one is unable to identify the sex from the genitalia unless they are extruded, but one must instead use other characteristics varying in the two sexes-those commonly called secondary sexual characters. Those abdomens which terminate with most of their distal segments and appendages in view, show projections of a tactile, clasping, or other function, and, although usually bilateral in arrangement, they are very irregular in appearance by contrast with those smooth forms described above. Here, of course, it is very often possible to tell the sex easily from the genitalia alone.

The anus is always surrounded by cuticular membrane divided into folds generally called anal lobes. It is often difficult to decide upon the number of the distal segment in adult insects because it cannot be differentiated from this membrane which may very well be made up, morphologically, of more than one segment.

In numbering the segments of this region it is not necessary to begin with the first abdominal one. The most caudal pair of 
abdominal spiracles typically occurs in the eighth abdominal segment of adult insects, but is sometimes concealed if the posterior segments are retracted; otherwise, it is in the seventh, and the arrangement in this particular is quite uniform throughout an order. As, for example, there are always eight pairs of abdominal spiracles in the Orthoptera but only seven pairs in the Lepidoptera, with the possible exception of Hepialus. The fact must not be lost sight of that in the larva of this form eight pairs of functional spiracles are present, and that these are rudimentary in the pupa. The caudal appendages of the abdomen, the genitalia, are designated in this paper by the Roman numerals I, II, III and IV, beginning with the cephalic pair. No attempt has been made to apply the names given by systematists to these parts.

With the foregoing general principles in mind, some account of the details of the work may now properly be considered.

Method of Preparation.-The method of preparing insects for a study such as the following is very simple. They were softened by leaving the entire insect, the abdomen only, or merely the posterior end, whichever was desired, in a five per cent solution of caustic potash for periods varying from twelve to twenty-four or thirty-six hours, depending upon the hardness and freshness of the specimens used. If pinned specimens were used, they were first boiled in water for a short time. They were then washed in running water, and studied under a binocular dissecting microscope. A compound microscope was also used for studying mounted balsam preparations of the smaller parts.

Discussion AND TABLES. - The arrangement of this section of the paper will be as follows: The Apterygota will be taken up first, and next the Pterygota, beginning in each case with the generalized forms. There are also included tables showing the sclerites and appendages present in the species studied. The presence of a sclerite or a pair of appendages is indicated in the tables by a plus sign, and their absence by a minus sign. When either is rudimentary, an asterisk is added to the plus sign. The abbreviations $t$ and $s$ stand for tergum and sternum respectively.

a. Thysanura.-It is obvious from the figures of both Lepisma and Machilis that the problem is complicated in the Thysanura rather than simplified, as would seem natural. . It is 
here that Heymons makes his best point in regard to the homologies between styles and genitalia, but in these forms both styles and appendages are often attached to the same somites. A careful survey, however, of Figure 12 (Plate IV) of the more generalized female shows that the latter are important outgrowths, which so far as the adults are concerned, may far better be considered genitalia than styles. In the embryos figured by Heymons the buds, anlages of genitalia and styles, are so near together as to be easily confused and to give ground for the belief that they are one and the same thing, not separate from the very beginning. On the other hand, this separation shows very clearly in his figures, even in those of insects which have entirely degenerate styles; that is, none, in the adult. He, however, does not interpret his figures nor yet his material in that way. He considers that the appendages found in the adult are simply the final specialization of these same abovementioned styles.

In the male and female Lepisma (Plate IV, Figs. 6, 7, 10, and 12), again it is evident that in the adult insect there are appendages corresponding to Appendage I as well as styles, on the same somite, and it seems unnecessary to correlate those appendages found on the terminal somite of Lepisma and Machilis with styles when they resemble so closely certain appendages, cerci or Appendage IV, of similar form in many groups where styles are not present. It should be said in this connection that the terminal median appendage present in the Lepisma and shown in the figures of that insect is the one which, including also the anal lobes, Heymons and Uzel homologize with the eleventh somite.

Table of Sclerites and Appendages.

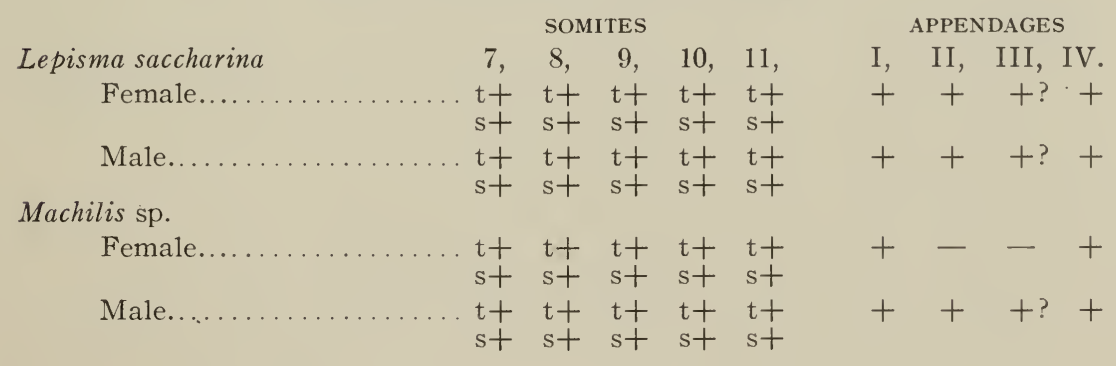


b. Orthoptera.-In regard to the Orthoptera it may be said that they are of course here, as elsewhere in structure, a very generalized group. To begin with, the tables show the presence of eleven, or at least parts of ten, somites and all four pairs of appendages in all the forms studied. This is particularly remarkable in connection with Appendage II, the commonly called "mesal," or "median" pair of appendages, which are so many times entirely lacking in the female.

In no case is the latter pair so prominent in the above mentioned genera as in Mantis. However, in case of every modification of the genitalia, whether it be for the purpose of digging in the ground, as is true in the grasshopper and the cricket, or whether for holding the spermatophore, the habit of the female Xiphidium, it is possible easily, not only to work out and see plainly this appendage, Appendage II, but also to see that it follows immediately upon Appendage $I$ in an extreme ventrocaudal position.

Table of Sclerites and Appendages.

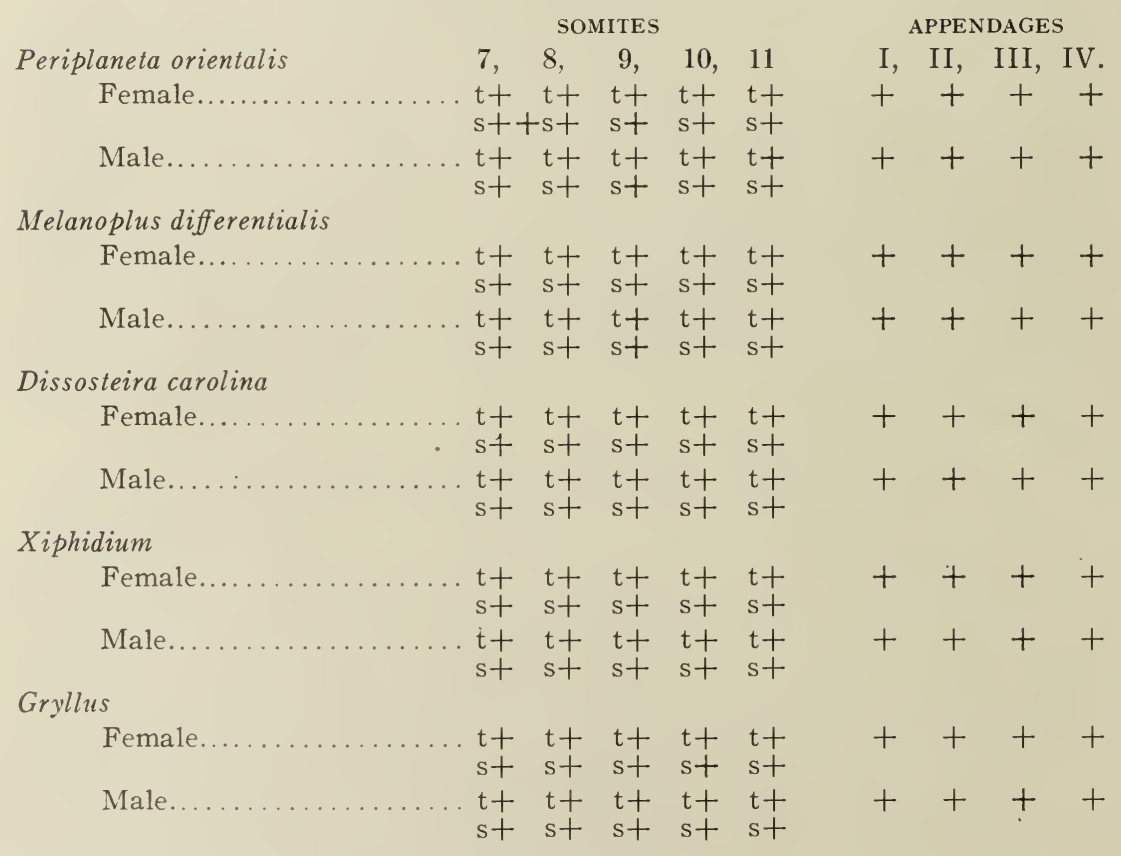


c. Hemiptera.-In many species of this order we meet the problem presented by Berlese's theory of successive pairs of cerci, which he illustrated by many examples from the Hemiptera. At the posterior end of Benacus, Zaitha and other species of aquatic Hemiptera, in both the male and female there projects a pair of strap-like appendages, included by some authors among the genitalia. Upon a close examination they are found to be outgrowths of the eighth tergites, and the corresponding pair of spiracles is situated at their bases. From these spiracles two parallel rows of closely set setæ extend to the distal ends of these projecting tergites. Various observers have believed them to be organs used in connection with the respiration of these aquatic species. The seventh tergite of Benacus presents a similar modification, and it contains the seventh pair of spiracles, but it is much broader and shorter. The seventh and eighth tergites of Notonecta and the eighth tergite of Corixa are apparently lengthened in like manner, and, according to some investigators, have also a like function. Euschistus variolarius and Anasa tristis, among the land forms, show similar projections from the tergites of this region, but lack the arrangements of setæ which have to do with the respiration of the aquatic species. However, in neither case are these parts separated from the sclerite proper, as is always true of the cerci, whether or not they show segmentation. In this connection, it may be noted that these prolongations in the Hemiptera, called by Berlese the cerci, are never segmented. The Hemiptera form a generalized order of insects, yet they are among the most specialized of those having an incomplete metamorphosis.

There are, therefore, few appendages present in certain of the more highly developed species, as is evident from the following table, and they are also specialized by modification in the form of complicated mechanisims. Examples of the latter are seen in the males of both Euschistus and Anasa. 
Table of Sclerites and Appendages.

\begin{tabular}{|c|c|c|c|c|c|c|c|c|c|}
\hline \multirow{3}{*}{$\begin{array}{r}\text { Tibicen septemdecim } \\
\text { Female....... }\end{array}$} & \multicolumn{4}{|c|}{ SOMITES } & \multirow[b]{2}{*}{11} & \multicolumn{4}{|c|}{ APPENDAGES } \\
\hline & 7 & 8 & 9 & 10 & & $\mathrm{I}$, & II, & III, & IV. \\
\hline & $t+$ & $t+$ & $\mathrm{t}+$ & $\mathrm{t}+$ & & + & + & + & + \\
\hline & $3+$ & $5+$ & 57 & st & & 1 & & & \\
\hline \multicolumn{10}{|l|}{ Notonecta undulata } \\
\hline Female...... & $t+$ & $t+$ & $t+$ & $t+$ & $t-$ & + & + & + & 一 \\
\hline & $s+$ & $s+$ & $s+$ & $s+$ & s- & & & & \\
\hline Male... & $t+$ & $t+$ & $t+$ & $t+$ & t- & + & + & + & - \\
\hline \multicolumn{10}{|l|}{ Benacus griseus } \\
\hline Female & $t+$ & $t+$ & $t+$ & $t+$ & $t-$ & + & - & + & - \\
\hline & $s+$ & $s+$ & $s+$ & $s+$ & $t-$ & & & & \\
\hline Male.. & $t+$ & $t+$ & $t+$ & $\mathrm{t}+$ & $t-$ & + & + & + & - \\
\hline \multicolumn{10}{|l|}{ Corixa sp. } \\
\hline Female & $t+$ & $t+$ & $t+$ & $t+$ & $t-$ & $t^{*}$ & - & - & - \\
\hline & s+ & $s+$ & $s+$ & $s+$ & $\mathrm{s}$ - & & & & \\
\hline 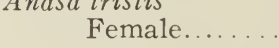 & $t+$ & $t+$ & $t+$ & $t+$ & $t+$ & $t^{*}$ & $t^{*}$ & Anasa tristis & - \\
\hline & $s+$ & $s+$ & $s+$ & $s+$ & $s+$ & & & & \\
\hline Male. & $t+$ & $t+$ & $t+$ & $t+$ & $t-$ & + & + & + & - \\
\hline \multicolumn{10}{|l|}{ Euschistus variolarius } \\
\hline Female... & $t+$ & $t+$ & $t+$ & $t+$ & $t-$ & $t^{*}$ & - & - & 一 \\
\hline & $s+$ & $s+$ & $s+$ & $s+$ & $s-$ & & & & \\
\hline Male. & $t+$ & $t+$ & $t+$ & $t+$ & $\mathrm{t}-$ & + & + & + & - \\
\hline & st & $s+$ & $s+$ & st & $s-$ & & & & \\
\hline
\end{tabular}

d. Neuroptera.-Here again, among the first of those forms characterized by a complete metamorphosis, we find a more generalized condition than among the Hemiptera, which, although they have an incomplete metamorphosis, stand at the top of the group. Appendage II is lacking, but this is the abovementioned "mesal" appendage more often absent than present.

To be sure, somite eleven is apparently entirely wanting, but without embryological evidence one has always a suspicion that parts of this segment may be present in the membrane of the anal lobes. Another point to be noted here, unlike any we found in the Orthoptera, is that the male appendages present almost as primitive a condition as do the female. In fact there is even less specialization in connection with function in the male than in the female.

Table of Sclerites and Appendages.

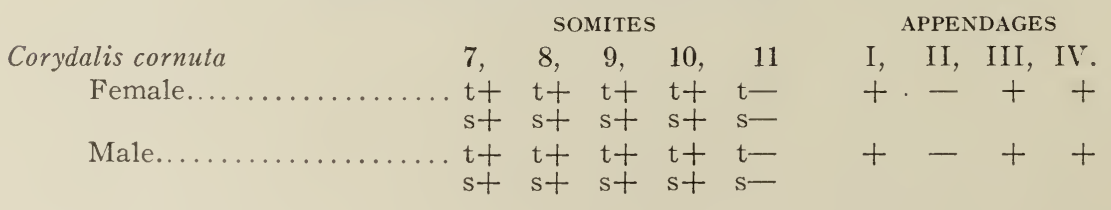


e. Mecoptera.-Panorpa lugubris, the example chosen in this case, seems at first glance to be a most specialized insect, particularly so far as genitalia are concerned. This appearance is found to be, with very little and superficial examination, entirely misleading. The real situation at the posterior ends of both the male and female Panorpa is that of a generalized form. In the male there is a resemblance to the Lepidoptera in the claspers, which are not, however, the only appendages present as is usually the case in the larger group characterized by such organs.

TABle of Sclerites and Appendages.

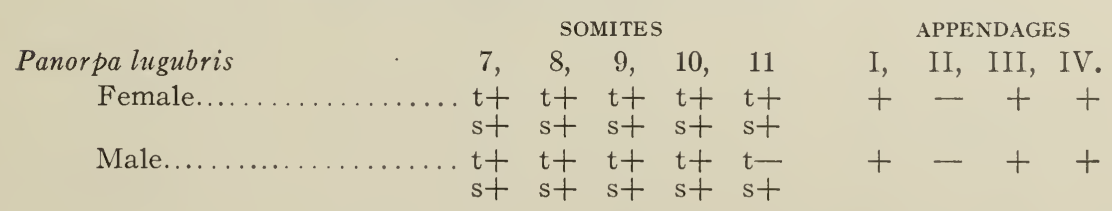

f. Trichoptera.-The male caddis fly is characterized by an apparent specialization, real indeed so far as function is concerned but not fundamentally affecting the relative arrangement of parts. The specialization is in connection with the prolongation merely of the ejaculatory duct, and is formed of Appendage II.

TABle of Sclerites ANd APPENDAGEs.

\begin{tabular}{|c|c|c|c|c|c|c|c|}
\hline \multirow[b]{2}{*}{$\begin{array}{l}\text { Nerophilus californicus } \\
\text { Female........... }\end{array}$} & \multicolumn{4}{|c|}{ SOMITES } & \multicolumn{3}{|c|}{ APPENDAGES } \\
\hline & 7, & 8 & 10 & 11 & I, & II, & III, IV. \\
\hline Male...... & $\begin{array}{l}\mathrm{t}+ \\
\mathrm{s}+\end{array}$ & $\begin{array}{l}t+t+ \\
s+s+\end{array}$ & $\begin{array}{l}\mathrm{t}+ \\
\mathrm{s}+\end{array}$ & $\begin{array}{l}\mathrm{t}+* \\
\mathrm{~s}+^{*}\end{array}$ & + & + & + \\
\hline
\end{tabular}

g. Coleoptera.-The Coleoptera have long presented a great problem to those investigators who wished to be able to make a classification of that group based on genitalia. So far as this paper is concerned they may still present almost unsurmountable difficulties. However, there is very little doubt that ten segments and even traces of eleven are present in the beetles, even if one must depend in large measure upon membrane only and asymmetrically placed sclerites. With relaxation by potash it is very evident that true somites eight, nine, and ten are present, the sutures between them showing plainly by means of evaginated folds or grooves. The eighth somite is always indicated plainly by the position of the eighth spiracle, no 
matter how much it is hidden from view at first glance. Appendages are in large measure lacking in the female and the appearance is that of extreme specialization by reduction. The male is modified especially in connection with the external opening of the ejaculatory duct, which is placed at some distance outside of the body-cavity, entirely out of relation to its respective somites 9 and 10 .

Table of Sclerites and Appendages.

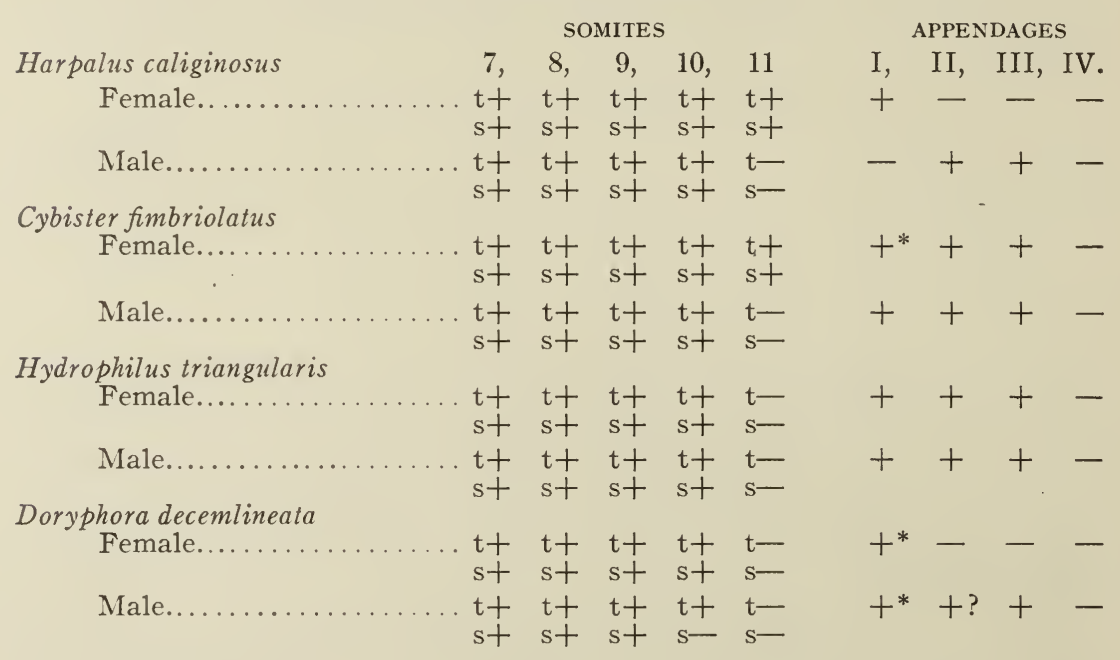

h. Lepidoptera.-The families of Lepidoptera present in the female, beginning with Hepialus, most extreme cases of specialization by reduction. The telescoping of segments is here carried to such a degree that we see for the first time the most terminal spiracle in the seventh somite instead of in the eighth, its usual position in a more typical form. It is interesting to note, in this connection, that this spiracle is present in the larva, rudimentary in the pupa, and lost in the adult, with the possible exception of Hepialus.

The somites retracted are very long in proportion to their width, and very slightly chitinized. Appendages in the female are largely lacking except perhaps for bud-like outgrowths from the somites at the positions occupied by appendages when present in other forms. The appearance of the female from the caudal point of view presents, particularly in Hepialus, because of this relation between somites and the origins of their respec- 
tive pairs of genitalia, a most generalized condition. The use of the word generalized may be objected to in a case of such extreme specialization, but certainly the relation between somites and appendages is a primitive characteristic in itself, and one extremely prominent in this group.

Table of Sclerites and Appendages.

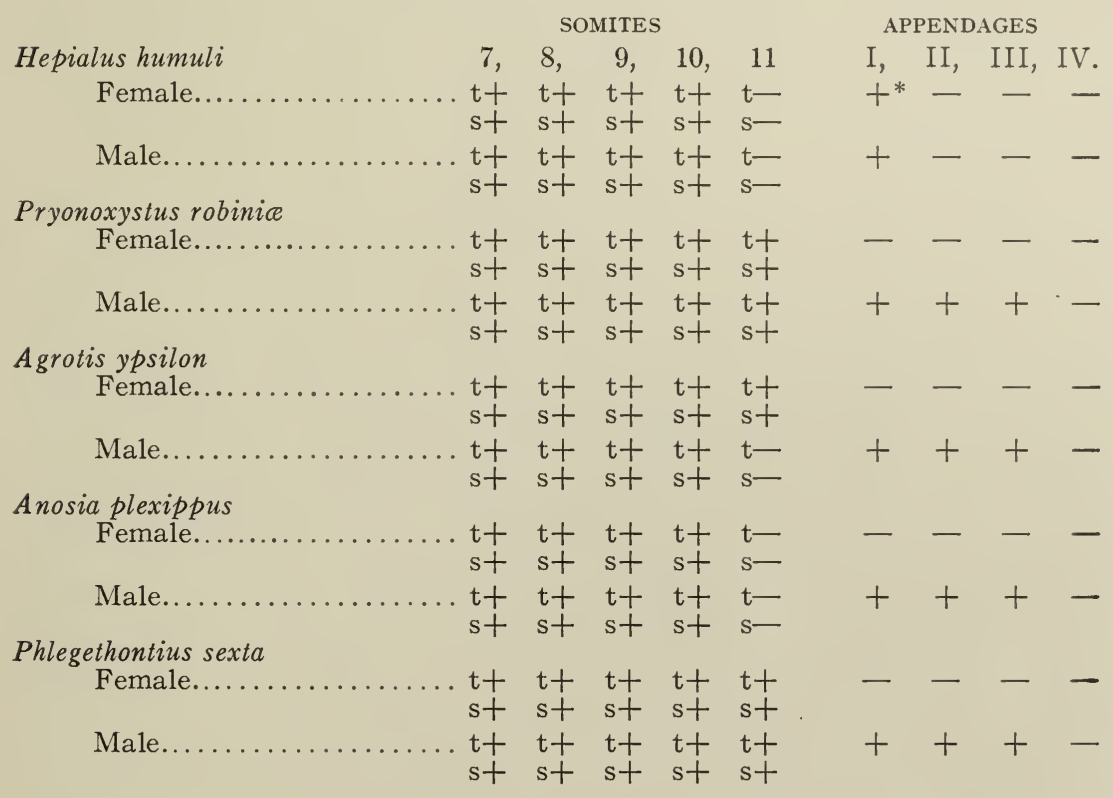

i. Diptera.-The Diptera differ among themselves largely in presenting both very generalized and specialized conditions. The specialization, so far as appendages is concerned, is again one of reduction. The best illustration of generalization is seen in the female of Tipula abdominalis and specialization is evident in the tabanid. A caudal view (Plate XVI) illustrates extreme specialization by reduction with scarcely any appendages indicated except the cerci, Appendage IV. In this as well as in all cases of this type of specialization both the anal and the genital openings occupy their typical position. The male shows greater specialization both in Appendage IV and in the other appendages, especially in the one forming the case for the ejaculatory duct, Appendage II, but even here, comparatively speaking, specialization by modification and enlargement of parts is fairly slight. 
Table of Sclerites and Appendages.

\begin{tabular}{|c|c|c|c|c|c|c|c|c|c|}
\hline \multirow{3}{*}{$\begin{array}{l}\text { Tipula abdominalis } \\
\text { Female........ }\end{array}$} & \multicolumn{5}{|c|}{ SOMITES } & \multicolumn{4}{|c|}{ APPENDACES } \\
\hline & 7 & 8 & 9 , & 10 & 11 & I, & II, & III, & IV. \\
\hline & $t+$ & $t+$ & $t+$ & $t+$ & $t-$ & $+?$ & - & - & + \\
\hline & $s+$ & $s+$ & $\mathrm{s}+$ & $s+$ & $s-$ & & & & \\
\hline Male. & $t+$ & $t+$ & $\mathrm{t}+$ & $t+$ & $\mathrm{t}-$ & + & + & + & + \\
\hline abanus sulcifrons & s+ & $\mathrm{s}+$ & $s+$ & s+ & $\mathrm{s}$ - & & & & \\
\hline Female. & $t+$ & $t+$ & $t+$ & $t+$ & $t-$ & 一 & - & - & - \\
\hline & $\mathrm{s}+$ & s+ & $\mathrm{s}+$ & $s+$ & $\mathrm{s}$ - & & & & \\
\hline Male.. & $t+$ & $t+$ & $t+$ & $t+$ & $t$ - & + & + & + & + \\
\hline alliphora viridescen & $s+$ & s+ & s+ & s十 & $\mathrm{s}$ - & & & & \\
\hline Female. & $t+$ & $t+$ & $t+$ & $t+$ & $\mathrm{t}$ - & 一 & - & 一 & - \\
\hline & $s+$ & s+ & $\mathrm{s}+$ & $s+$ & $\mathrm{s}-$ & & & & \\
\hline Male.. & $t+$ & $\mathrm{t}+$ & $t+$ & $t+$ & $t-$ & $+^{*}$ & + & + & + \\
\hline & s+ & s+ & $\mathrm{s}+$ & $s+$ & $\mathrm{s}$ - & & & & \\
\hline
\end{tabular}

j. Hymenoptera.-The connections of the Sth and 9th somites with their respective genitalia are very clearly seen, not only in the generalized saw-fly, Dolerus, but also in the specialized Vespa (Plate XVII). The genitalia, here having the form of saws and stings respectively, are in themselves very naturally greatly modified for their functions, but, except for their length and serrated edges, for example, there is very little about the posterior ends of the females of either of the above mentioned genera which indicates very great specialization. The one point which does strongly suggest such specialization is the complete retraction of parts in this region of the body so that without potash preparations one would see only a perfectly even contour in the caudal region of the abdomen.

The males of this order show numerous small modifications of all the genitalia, Appendages I, II, III, and IV respectively. These modifications are in the form of many irregular points, curved projections, finger-like evaginations, and other small structures hard to describe. The copulatory habits of these forms have been worked on so little that nothing can be said with regard to the meaning of all these structures. Their positions in relation to their respective segments are not difficult to make out, as is evident from the plates showing figures of these forms. 
Table of Sclerites and Appendages.

Dolerus unicolor

Female...

Male.

Vespa maculata

Female....

Male........

$$
\text { SOMITES }
$$$$
\begin{array}{lcccc}
7, & 8, & 9, & 10, & 11 \\
t+ & t+ & t+ & t+ & t- \\
s+ & s+ & s+ & s+ & s- \\
t+ & t+ & t+ & t+ & t- \\
s+ & s+ & s+ & s+ & s-
\end{array}
$$$$
\text { it } t+t+t+t-
$$

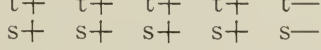$$
\begin{aligned}
& \mathrm{t}+\mathrm{t}+\mathrm{t}+\mathrm{t}+\mathrm{t}- \\
& \mathrm{s}+\mathrm{s}+\mathrm{s}+
\end{aligned}
$$

APPENDAGES

I, II, III, IV.

+++ +

$+++-$

$+++-$

$+++-$

III. SUMMARY.

Comparisons between certain of the somites of the different orders investigated, as well as between some of the appendages studied, may well be taken up as a summary of the above discussions and tables. The homology of the sclerites of the species studied, as well as that of the appendages, has been fully and clearly indicated in the labeling of the figures.

1. Somite Eight.-This somite, as has already been noted, contains, typically, the terminal pair of spiracles. Except in those species which have well-rounded contours, or are pointed, at the caudal end of the abdomen, this somite approaches very nearly the one figured in the so-called primitive type (Plate IV, Fig. 1). It is simple in outline; broad and blunt in shape; about one-third as long as wide; tapering only very slightly, if at all, and with a tergum and sternum almost equal in size, connected laterally by an appreciable conjunctiva; in the Thysanura, Orthoptera, Hemiptera, and in the generalized orders studied having a complete metamorphosis, such as the Neuroptera, Mecoptera, and Trichoptera. In the Coleoptera and Lepidoptera it is retracted; more or less membranous; long in proportion to its width; and, in the Lepidoptera, except for the possible case of Hepialus, it lacks its respective spiracle. It is also small in the higher families of the Diptera, but its extreme specialization occurs in the female Hymenoptera where the sternum consists of two small, sub-triangular sclerites to which is attached its respective pair of appendages, I, saws or sting as the case may be. (Plate XVII, Figs. 10 and 14).

2. Somite Nine.-This somite is more specialized than the eighth and markedly shorter in proportion to its width even in the Thysanura and Orthoptera. In these generalized orders of 
insects, with incomplete metamorphosis, the ninth somite shows specialization in the sterum, which, early in its history in the female cockroach and grasshopper, is much smaller and far more variable in shape than the tergum. In the Hemiptera it is a larger, less modified somite, in the sternum as well as in the tergum, and this continues to be true in Corydalis and Panorpa, although it is longer in proportion to its width than before, this latter characteristic following out the general shape of the scorpion fly. In the Coleoptera the entire somite consists of most irregularly shaped chitinous sclerites, and, in large proportion, of cuticular, non-chitinized membrane. Such sclerites may not be bilaterally placed with reference to the shape of the beetle, but in a direct ventral view only a part of the sternum will show, and that, irregular in shape, as in Hydrophilus (Plate XIII). In the Lepidoptera the ninth somite is often a homogeneous, membranous cylinder as in the females of Phlegethontius and Pryonoxyatus; or, as in the male of the same genus there may be a slender, curved sclerite bilaterally placed in a broad area of membrane; or, as is true of Hepialus the sclerites may be broad and short, more highly chitinized than the succeeding somites. In the Diptera it varies from the small, crescent-shaped sternum of the female Tipula abdominalis, to the broad, well-rounded tergum of the male in the same species.

Between these two extremes, one finds every irregularity, of size and shape, as is well illustrated by the long, sub-cylindrical somite of the male blow-fly and the irregularly chitinized, largely membranous sternum of the female of the tabanid. The corresponding sclerite in the male further accentuates the shape found in the female so that it is almost forked, the points projecting posteriorly and, in the female blow-fly we meet with an almost typical ninth sternum, its only variation being a somewhat curved caudal margin.

The ninth sternum is highly specialized in shape and arrangement in the Hymenoptera, after the same manner already commented upon in connection with the eighth, and it consists of two irregular sclerites again somewhat approaching a triangular shape. However, just as plainly marked as in the case of the eighth, is the primitive connection of this sternite with its respective pair of appendages: a most generalized point in a highly specialized group. It should also be noted that this 
generalized condition is almost as clearly seen in Vespa as in the saw-fly.

3. Somite Ten.-The typical form of this somite holds good, for the tergum in the male and female Lepisma, the sternum in these forms having as its main characteristic a deep indentation in the middle of the caudal margin. In the grasshoppers this tergum is narrow and only partly divided from the ninth by an incomplete suture, in both male and female, but the sternum is nearly typical. In the female cockroach it is so deeply indented in the middle of the caudal margin as to seem almost forked, and in the male this sclerite is very short with an entire, caudal margin, while the sternum is very small and retracted in both cases. In the male and female crickets the tergum is a sclerite nearly as long as broad, with a well-rounded caudal margin, but the sternum is smaller, much shorter than broad; and indented on the caudal margin, as is also the tergum of the female Xiphidium. The sternum again in this genus, as in all of the Orthoptera studied, shows specialization to a slight degree in its being retracted under the preceding sterna and terga with a consequent reduction in size. In the Hemiptera this small size of somite ten, with its accompanying retraction, is carried to a greater extent, and we have small sclerites, still chitinized, and, for all those studied, very well illustrated by the terminal tergum of Benacus which is typical of such sclerites, well developed, considering that they are retracted. The latter point is clear when such a tergum is compared with the tenth tergum or sternum of Euschistus. In all the Hemiptera studied there was quite perceptible chitinization of the cuticula forming the tenth somite, but this is lacking in the Neuroptera where membrane only is present. The somite in this case is not only short, but also small in circumference, entirely covered by other somites and appendages, and enclosing the anus without very well-marked sutures between the tergum and sternum. Such a description as this would answer for the tenth somite of almost any form taken through the remaining insect orders considered. Exceptions may be made in the case of Panorpa where the whole somite is long in proportion to its width, and firmly chitinized; in forms as reduced and retracted as Hepialus and Tabanus, where the length is very short in proportion to the width; in the female Pryonoxystus, where it is retracted and membranous, yet long and cylindrical. 
4. Somite Eleven.- Somite eleven, as has been shown in the tables, occurs the most infrequently of any of the four caudal somites studied. It is the most characteristic of the Orthoptera of any order, although it also occurs in certain generalized families. When present it is posterior to the tenth, surrounds the anus, and is membranous except in such forms as the female grasshopper, where its tergum is highly chitinized, and clearly separated from the tenth tergum by a well-marked suture. Posterior to it in those cases, in the adult, lies the so-called twelfth somite of Heymons showing in both Dissosteira and Melanoplus (Plate VI, Figs. 9 and 10; 1, 10, 13, and 17, t12) very distinct in the female. This suture is not, however, present in certain nymphal stages, according to many investigators, even when it appears in the adult, and it would seem, therefore, to be a secondary modification. In other orders than the Orthoptera the eleventh somite is a short, homogeneous, membranous ring surrounding the anus, often distinguishable with difficulty from the anal lobes.

5. General Statement.-Of the four somites considered above, it is evident that the ninth is the most specialized of all, both by reduction of parts, by modification of form, and by lack of chitinization-all three characteristics following upon retraction of the caudal end of the abdomen. Somite eight changes least from its form in the primitive type, and in the generalized Orthoptera, somites ten and eleven become the simplest in form, structure and substance, by specialization and reduction of parts.

6. Appendage I.-This appendage occupies the most extreme ventro-caudal position, and shows its real connection with somite eight only in the saw-flies and wasps. This pair of appendages usually seems to be placed closely adjoining the ninth sternum, and is often referred to as the ventral pair of appendages. The ventral pair of ovipositors of the grasshopper (Plates V and VI) show this relative position, although the connection would appear at first glance to be with the eighth. This is also true in Appendage I in the female Lepisma. This appendage belongs to the eighth somite, but is often crowded out of its typical position by the shape, retraction, and function of the caudal somites. The Hymenoptera present another and one of the clearest cases of the relation between Appendage I 
and somite eight, as has already been mentioned in another connection. This is well illustrated by the female saw-flies and Vespa (Plate XVII, Figs. 10 and 14) as well as by the generalized genus Lepisma in the male. The size of these appendages varies with their function. In the Orthoptera they attain a good size in all the forms studied, in both the male and the female, being more prominent in the latter. They are often apparently small tactile organs in the male when Appendages II and III are highly specialized, as in the case of Benacus, Euschistus and Anasa, Appendage I being even less conspicuous in the females of the two last mentioned genera, and somewhat smaller than in the male. In those groups having a complete metamorphosis it is either rudimentary, as in the female Hepialus; absent altogether as is most often the case in both the male and female of the Coleoptera and in female Lepidoptera other than Hepialus; or specialized as so-called claspers in most male Neuroptera, Mecoptera, Trichoptera, and Lepidoptera other than Hepialus. In the Diptera, it is rudimentary in the female Tabanus; of good size in both the male and female Tipula, and in the male Tabanus; and small in both sexes in Calliphora.

7. Appendages II AND III.-These appendages are prominent in those females which have their genitalia specialized to dig holes in which to lay their eggs, to sting, or to perform some other accessory function. Examples of these are common among the Orthoptera and Hymenoptera (Plates V, VI, VII and XVII). Even here Appendage II, referred to above as the "mesal" appendage of certain authors, is small or rudimentary, and it is found to be more often absent altogether in the female than in the male. In the male these appendages are most specialized in connection with the intromittent organ, and Appendage II is more often present in the male than in the female. The best examples of this modification are seen in the Hemiptera and Coleoptera (Plates VIII, IX, X, XI and XII). Similar organs, much smaller in size, are also found in Corixa, Notonecta, Corydalis, Dolerus, and Vespa, made up, in all these cases of Appendage II, as well as III.

8. Appendage IV.-Appendages included under this head are most often called the cerci. These are more dorsal in position than the others, and seem in many cases in adults, especially in the Orthoptera, to be as well attached to somite ten as 
to eleven. (Plates V, VI and VII). Here we have the only instance of the association of one of the genitalia with terga rather than with sterna, so far as the sclerites are concerned, but the membrane forming the tenth and eleventh sterna is also in close contact with the base of this appendage. Wheeler, in his work on the embryo of Xiphidium, shows this appendage attached to the eleventh somite. It seems likely that variation in the form of these appendages accompanies a change in function. Evidence of this may be noted in the varied cerci of the Orthoptera, Neuroptera, Mecoptera, Trichoptera, and Diptera.

The main conclusion emphasized is the descent of the male and female genitalia from the anlages of abdominal, pedal extremities of a myriapod-like ancestor, as seen in the embryos of insects. The stylets upon which so much emphasis has been laid by investigators, mainly represented by Heymons, certainly have little place in the adult insect. That they are present in the Thysanura seems to have little weight after one has worked upon representatives not only of that order but of many other groups, because even where such stylets are present there are also present far more important structures, the above. mentioned genitalia. Even in Heymons's figures it is clear that the two descended from entirely separate anlages, and the interpretation that the genitalia descended from the anlages of stylets seems entirely unnecessary, and in fact, in one case at least, entirely wrong.

That there are traces in the adult insect of ten, eleven, or possibly twelve somites, would seem but natural considering the probability of a far greater ancestral number, but only somites eight, nine, ten, and eleven bear a direct relation to the genitalia. 


\section{BIBLIOGRAPHY.}

Ayers, H.-On the Development of the Oecanthus niveus and its Parasite Teleas. Mem. Bost. Soc. Nat. Hist., 3, 1884.

Berlese, A.-Gli Insetti. Societa Editrice Libraria, 1909, Milano.

Bordas, L.-Anatomie des organes appendiculaires de L'appareil reproducteur femelle des Blattes (Periplaneta orientalis L.). C. R. Acad. Sc., Paris, 147, 1415-18.

Borner, Carl.-Die Phylogenetische Bedeutung der Protura. Biol. Centralb., 30, 1910, 633-41. Zür Klärung der Beingliederung der Ateloceraten. Zur Systematik der Hexapoden. Zool. Anz., 27, 1904, 226, 511.

Burmeister, H.-Handbuch der Entomologie. Berlin, 1832.

Carriere, J.-Bemerkungen zu der Arbeit von A. Giardina. Anat. Anz., 22, 1903, 381-7.

Chadima, J.-Ueber die Homologie zwischen den männlichen und weiblichen äusseren Sexualorganen der Orthoptera Saltatoria Latr. Mittheil. naturwiss Vereins Steiermark, 1872, 25-33.

Cholodkovsky, N.- Die Embryonalentwicklung von Phyllodromia (Blatta) germanica. Mem. Acad. St. Petersburg, 38, 1891. Studien zur Entwicklungsgeschichte der Insekten (Blatta germanica). Zeits, wiss, Zool., 48, 1889. Ueber die Bildung des Entoderms bei Blatta germanica. Zool. Anz., 1888, Ueber die Entwicklung des centralen Nervensystems bei Blatta germanica. Zool. Anz., 14, 1891. Zur Embryologie der Hausschabe, (Blatta germanica). Biol. Centralbl., 10, 1890. Zur Embryologie von Blatta germanica. Zool. Anz., 1890, On the Morphology and Phylogeny of Insects, (Reviews). Ent. News, IV, 1893, 52-53. Zool. Anz., 14, 1891 .

Davis, H.-Notes on the Pygidia and Cerci of Insects. Jour. R. Microscop. Soc., 2, 1879 .

Dewitz, H.-Beiträge zur Kenntniss der postembryonalen Gliedmassenbildung bei den Insecten. Zeits. wiss. Zool., 30, suppl., 1878. Ueber Bau und Entwickelung des Stachels und Legescheide einiger Hymenopteren und der grünen Heuschrecke. Zeits. wiss. Zool., 24, 1875.

Dohrn, A.- Notizen zur Kenntniss der Insectenentwicklung. Zeits. wiss. Zool., 26, 1876.

Dufour, L.- Recherches anat. et Physiol, sur les Orthopteres, etc. Memoires Présentés. par div. sav., 7, Paris, 1841.

Escherich, K.-Das Insekten-Entoderm. Ein Beitrag zur Keimblätterlehre. Biol. Centralb1., 21, 1901, 416-31. Die Biologische Bedeutung der Genitalanhänge der Insekten. Verhandl. zool.-bot. Ges., Wien., 1892. Vorläufige Erwiderung auf Verhoeff's Kritik über meine Arbeit über die biologische Bedeutung der Genitalanhänge der Insekten. Ent. Nachr., 19, 1893, 129.

Fenard, A.- Recherches sur les organes complementaires internes de l'appareil genitale des Orthopteres. Bull. sc. France-Belg., 29, 1897.

Ganin, M.-Beiträge zur Erkenntniss der Entwicklungsgeschichte bei den Insekten. Zeits. wiss Zool., 1869. Beiträge zur Erkenntniss der Entwicklungsgeschichte bei den Insekten. Zeits. wiss. Zool., 19.

Graber, V.-Beiträge zur vergleichenden Embryologie der Insekten. Denkschr., Akad. Wien, 58, 1892, 803-66. Die Insekten. Erster Thiel, 1877. 221-9. Ueber den Bau und die Phylogenetische Bedeutung der embryonalen Bauchanhänge der Insekten. Biol. Centralb., 9, 1889. Ueber die Polypodie bei Insectenembryonen. Morph. Jahrb., 14, 1888. Ueber die Primäre Segmentirung des Keimstreifs der Insecten. Morph. Jahrb. 14, 1888. Vorlaufige Ergebnisse einer grösseren Arbeit über verbleichende Embryologie der Insecten. Archiv. mik. Anat., 15, 1878. Vergleichende Lebens und Entwicklungsgeschichte der Insecten. Naturkräfte, München, 1879, Vergleichende Studien am Keimstreif der Insecten. K. Akad. d. wiss. Vienna, Mat.-nat. ,K1., Denksch., 57, 1890. Vergleichende Studien über Keimhüllen und die Rückenbildung der Insecten. Denkschr., Mat.Naturw. kl. Acad. wiss., Wien, 55, 1888. Zur Embryologie der Insecten. Zool. Anz., 14, 1891. Die Aehnlichkeit in Baue der äusserweiblichen Geschlechtsorgane bei den Lokustiden und Akridiern auf Grund ihrer Entwickelungsgeschichte. Sitsber. der k. Akad. d. wiss. Wien, 61, 1870. Ueber die Morphologische Bedeutung der ventralen Abdominalanhänge der Insektenembryonen. Morph. Jahrb., 17,1891. 
Haase, E.-Die Zusammensetzung des Korpers der Schaben (Blattidæ). Sitzber. Ges. Nat., Fr.. Berlin, 1889, 128-136. Die abdominalanhänge der Insekten mit Berücksichtigung der Myriapoden. Morph. Jahrb., 15, 1889, 331-435.

Hallez, P.-Orientation de l'embryo et formation du cocon chez la Periplaneta orientalis. Compt. Rend. Acad. Sc., 101, 1885.

Henking, H.-Untersuchungen über die ersten Entwicklungsvorgänge in den Eiern den Insekten. III. Spezielles und Allgemeines. Zeits. wiss. Zool. 54, $1892,1-274$.

Henneguy, L. F.-Les Insectes, Morphologie-reproduction-embryogenie. Paris, 1904.

Hertwig, R.-Ueber die Anlage der Keimblatter bei den Insekten. Jen. Zeits. Naturw., 14, 1881, 124-8.

Heymons, R.-Die morphologische Bau des Insektenabdomens. Zool. Centralb1., 6, 1899, 537-556. Ein Beitrag zur Entwicklungsgeschichte der Insekta Apterygota. Sitzber. Akad, Berlin, 51, 1896. Beiträge zur Morphologie und Entwickelungsgeschichte der Rhynchoten. Nova Acta Acad. Leop. Car., 74, 1899. Die Embryonalentwicklung von Dermapteren und Orthopteren unter Besonderer Berücksichtigung der Keimblätterbildung. Monog. bearbeitet, Jena, 1895, 4. 136. Die Entwicklung der weiblichen Geschlechtsorgane von Phyllodromia (Blatta) germanica. Zeits wiss. Zool., 53, 1897. Die Hinterleibsanhänge der Libellen und ihrer Larven. Ann. Naturhist. Hofmus., Wien, 19, 1904, 20. Die Segmentirung des Insekenkörpers. Abh. Akad., Berlin, Phys. Abth., 1895, 39. Die verschiedenen Formen der Insektermorphose und ihre Bedeuteng im Vergleich zur Metamorphose anderer Arthropoden. Ergebn. und Fortschr. der Zool., 1, 1909, 137-188. Drei neue Arbeiten über Insektenkeimblätter. Zool. Centralbl., 12, 1905, 677-90. Ein Beitrag zur Entwicklungsgeschichte der Insecta Apterygota. Sitzgber. k. preuss. Ak. Wiss., Berlin, 51, 1896, 1385-89. Entwicklungsgeschichtliche Untersuchüngen an Leipsma saccharina L. Zeits. wiss. Zool., 62, 1897, 583-631. Entwicklung von Phyllodromia germanica. Verh. d. deutsch. zool. Gesel., 1892, 139-41. Ueber den Genitalapparat und die Entwicklung von Hemimerus talpoides. Zool. Jahrb., Supp. 15, Bd. 2, 1912, 141-184. Ueber die abdominalen Körperanhänge der Insekten. Biol. Centralb., 16, 854-64. Ueber die Bildung der Keimblätter bei den Insekten. Sitzungsber. d. k. preuss. Akad. zu Berlin, 1894. Ueber die Fortpflanzungund Entwicklungsgeschichte der Ephemera vulgata L. Sitzungsb. Gesell. Naturf. Freunde, Berlin, 1896, 81-96. Ueher die hermaphroditische Anlage der Sexualdrüsen beim Mannschen von Phyllodromia (Blatta L.) germanica. Zool. Anz., 13, 1890. Ueber die Lebensweise von Hemimerus. Deutsch. Ent. Zeits., Berlin, 1911, 163-174. Uebersicht über die neuere Ergebnesse auf dem Gebiete der Insektenembryologie. Zool. Centralb1., 1, 41-50, 81-92. Zur Morphologie der Abdominalanhänge bei den Insekten. Morph. Jahrb., 24, 1896.

Heymons, R. \& H.-Ueber die Keimhüllen von Machilis. Verhand1. deutsch. Zool. Gesells., 1905, 123-135. Die Entwicklungsgeschichte von Machilis. Verh. deutschen Zool. Ges., 15, 1905.

Klapalek, Fr.-Ueber die Gonopoden der Insekten und die Bedeutung derselben für die Systematik. Zool. Anz., 27, 1904, 449-53. Noch einige Bemerkungen über die Gonopoden der Insekten. Zool. Anz., 28, 1904, 255-9. $505-568$.

Knower, H. M.-The Embryology of a Termite. Journ. of Morph. 16, 1900,

Kolbe, H. I.-Einführung in die Kenntniss der Insekten. Berlin, 1893.

Kowalevsky, A.-Embyrologische Studien an Würmer und Arthropoden. Mem. Acad. St. Petersburgh, (7) 16, 1871.

Mayer, P.-Ontogenie und Phylogenie der Insecten. Jen. Zeits. Naturw., $10,1876$.

Melnikof, N.-Beitrage zur Embryonalentwicklung der Insekten. Arch. Naturg., 35, 1869.

Metchnikoff, E.-Embryologische Studien an Insekten. Zeits. wiss. Zool., 16,1866 .

Nussbaum, J.-On the Development of the Efferrent Ducts of the Genital Glands in Insects, Résumé in English. Royal Mic. Soc. Journ., Ser. 2, Vol. 3, 1883, 204-5. Zur Entwicklungsgeschichte der Ausführungsgänge der Sexualdrüsen bei den Insecten. Zool., Anz., 5, 1882. Zur Frage der Rückenbildung bei der Insektenembryonen. Biol. Centralb1., 10, 1890. Zur Frage der Segmentirung des Keimstreifs und der Bauchanhänge der Insektenembryonen. Biol. Centralbl., 9, 1889. 
Oudemanns, J. T.-Ueber die Abdominalanhänge einiger Lepismidae (Thermophila furnorum Rovelli.). Zool Anz., 12, 1899, 353-5.

Packard, A. S.-Embryology of Isotoma, a Genus of Poduridae. Proc. Bost. Soc. Nat. Hist., 1870. Embryological Studies on Hexapodous Insects. Mem. Peabody Acad. Sc., Salem, 1872. On the Structure of the Ovipositor and Homologous Parts in the Male Insect. Proc. Bost. Soc. Nat. Hist., 11, 1868. The Embryological development of the Locust. Third Rep. U. S. Ent. Com., Washington, 1883.

Patten, W.-The Development of Phryganids, with a preliminary note on the development of Blatta germanica. Q. J. Mic. Sc., 24, 1884.

Peytoureau, S. A.-Recherches sur l'anatomie et le developpement de l'armure genitale femelle des Insectes Orthopteres. Compt. rend. Ac. Sc., Paris, $117,1893,749-51$. Recherches sur l'anatomie et le developpement de l'armure genitale male des Insectes Orthopteres. Compt. rend. Ac. Sc., Paris, 116, 1893, 293-295. Contribution à L'étude de la morphologie de l'armure genitale des Insectes. Paris, 1895.

Philipschenko, Jur.-Beiträge zur Kenntniss der Apterygoten. III. Die Embryonalentwicklung von Isotoma cinerea Nic. Zeits. wiss. Zool., 103, 1912, 519-660. Zur Kenntniss der Apterygotenembryologie. Zool. Anz., 39, 1912, 43-49.

Ryder, J. H.-1. The Origin of the Amnion. 2. The Development of Anurida maritima. Am. Nat., 20, 1886.

Schaum.--Ueber die Zusammensetzung des Kopfes und die Zahl der Abdominal-Segmente bei den Insekten. Arch. Naturgesch., 29, 1863, 247, Nachtrag, 365.

Straus-Durkheim, H. E.-Traité pratique et théorétique d'Anatomie comparative. Paris, 1842.

Strindberg, H.-Embryologische Studien an Insekten. Zeits, wiss. Zool, 106, 1913, 1-227.

Tarzioni-Tozzetti, A.-Armature genitali maschili degli Ortotteri saltatori. Boll. Soc. Ent., Ital., 14, 1882, 384.

Uljanin, W. N.-Sur le developpement des Podurelles. Arch. Exp. Zool., 4, $1875 ; 5,1876$.

Uzel, H.-Beiträge zur Entwicklungsgeschichte von Compodea staphylinus. Zool. Anz., 20, 1897. Vorlaüfige Mittheilung über die Entwicklungsgeschichte von Compodea staphylinus. Zool. Anz., 20, 1897. Vorläufige Mittheilung über die Entwickelung der Thysanuren. Zool. Anz., 20, 1897, 125.

Verhœff, C.-Noch einige Worte über Segmentanhänge bei Insekten und Myriapoden. Zool. Anz., 21, 32-39. Bemerkungen über abdominale Korperanhänge bei Insecten und Myriapoden. Zool. Anz., 20, 293-300. Cerci und Styli der Tracheaten. Ent. Nachr., 21, 166-8, 1895. Ueber Diplopoden, Aufsatz: (Gervaisia) und Polyzonium. Zool. Anz., 32, 521-36, 1908. Vergleichende Untersuchungen über die Abdominalsegmente und due Copulationsorgane usw. Deutsche Ent. Zeits., Jng. 1893, 113-170, 209-260. Zur Morphologie der Segmentanhänge bei Inseckten und Myriapoden. Zool. Anz., 19, 511, 378-83; 512, 385-88.

Verson, E.-Zur Entwicklungsgeschichte der männlichen Geschlechtsanhänge bei Insekten. Zool. Anz., 27, 1904, 470.

Viallanes, H.-Sur quelques points de l'histoire du developpement embryonnaire de la Mante religieuse. Rev. biol. du Nord de la France, 2, 1890, or Ann. Sc. Nat. Zool., 11, 1891.

Wagner, J.-Einige Betrachtungen über die Bildung der Keimblätter, der Dotterzellen und der Embryonalhüllen bei Arthropoden. Biol. Centralbl., 14, 1894, 361-74.

Wattenwyl, Brunner von.-Die Morphologische Bedeutung der Segmente speziell des Hinterleibes, bei den Orthopteren. Festschrift fünfundzwanzig jährigen. Bestehens K. K. Zool.-Botan. Gesell. Wien, 1876.

Weismann, A.-Zur Embryologie der Insekten. Archiv. Anat. Physiol., 1864.

Wheeler, W. M.-A Contribution to Insect Embryology. Journ. Morph., 8, $1-160,1893$. On the Appendages of the first Abdominal Segment of Embryo Insects. Trans. Wis. Acad. Sci., Arts and Letters, 8, 1890. The Embryology of Blatta Germanica and Doryphora Decemlineata. Journ. Morph., 3, 1889. Neuroblasts in the Arthropod Embryo. Journ. Morph., 4, 1891. Note on the Oviposition and Embryonic Development of Xiphidium ensiferum Scud. Insect life, Washington, 2, 1890, 222-5. On the Appendages of the first abdominal segment of the embryo cockroach. (Blatta germanica). Trans. Wis. Acad. Sc., Arts and Letters, 8, 1890, 87-140. Ueber ein eigenthümliches Organ in Locustidenembryo (Xiphidium ensiferum). Zool. Anz., 13, 1890. 


\section{EXPLANATION OF PLATES.}

AbBreviations.

The following plates include figures of the posterior somites and appendages of the male and female forms of the insects studied. Other accessory points, such as external openings and their connections with their ducts, are shown wherever possible. Everything has been carefully and clearly labeled according to the following:

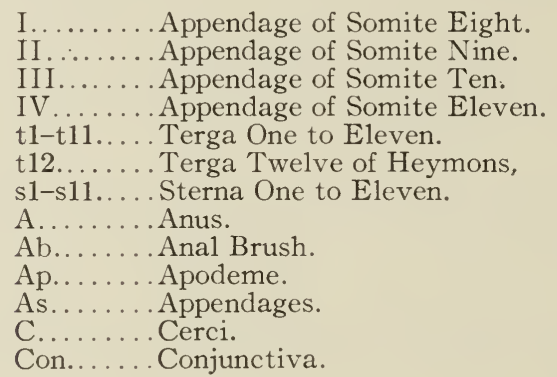

I......... Appendage of Somite Eight.

III......... Appendage of Somite Ten.

IV ........Appendage of Somite Eleven.

t1-t11.... Terga One to Eleven.

t12....... Terga Twelve of Heymons,

A.........Anus.

Ab........Anal Brush

Ap........ Apodeme.

C. Cerci.

Con....... Conjunctiva.

\section{Plate IV-Primitive Type and Thysanura.}

Primitive type, Fig. 1, ventral view.

Machilis sp., 2, \&, mesal view; 3 , \&, ventral view; 4 , $\sigma^{\nearrow}$, ventral view.

Lepisma saccharina, 5 , $\&$, dorsal view; 6 , $q$, ventral view; 7 , $ᄋ$, mesal view; 8 , $\circ$, ventral view; $9, \sigma^{7}$, dorsal view; $10, \sigma^{7}$, ventral view; $11, \sigma^{7}$, mesal view; $12,13, \sigma^{2}$, ventral views.

\section{Plate V-Orthoptera.}

Periplantea orientalis, 1 , ᄋ, lateral view; 2 , $९$, dorsal view; $3,4,5,6,11$, , caudal views; $8, \sigma^{2}$, ental and mesal view; 9 , o, ental view; 10 , $\sigma^{2}$, ventral view; 13 , $\sigma^{7}$, mesal view; $16, \sigma^{7}$, dorsal view.

Dissosteira carolina, 7, ㅇ, dorso-caudal view.

Mantis sp., 12, \&, lateral view; 14 ,, ventral view; 15 , $\&$, ental view.

Melanoplus differentialis, $17, \sigma^{7}$, dorso-caudal view.

\section{Plate VI-Orthoptera.}

Melanoplus differentialis, 1 ,, , lateral view; 2 , $९$, mesal view; 4 , $q$, mesal view; 5 , $ᄋ$, lateral view; $6, \sigma^{7}$, lateral view; 7 , 9 , ental view; $9, \sigma^{7}$, ventral view; $11,12 . \sigma^{7}$, mesal views; $13, \sigma^{7}$, dorsal view; $16, \sigma^{7}$, dorsal view; 17 , $ᄋ$, dorsal view; $18, \sigma^{7}$, lateral view; 19 , 9 , ventral view.

Dissosteira carolina, $3, \sigma^{7}$, ental view; $8, \sigma^{7}$, caudal view; 10 , 오, lateral view; 14 , \&, ental view; 15 , \& lateral view; 20 , $\circ$, mesal view.

\section{Plate ViI-Orthoptera.}

Gryllus pennsylvanicus, 1, 5, 10, caudal.views; 2, lateral view; 3 , 6, ventral views; 7 , 9 , dorsal view; $8, \sigma^{7}$, lateral and ental views; $9, \sigma^{7}$, ventro-caudal view; 10 , ठ, caudal view; $11, \sigma^{7}$, ventral view; $12, \sigma^{7}$, dorsal view; 15 , $\odot$, mesal view. Dissosteira carolina, $4, \sigma^{7}$, caudal view.

Xiphidium ensiferum, $13, \sigma^{7}$, dorsal view; $14,17, \sigma^{7}$, caudal view; $16, \sigma^{7}$, ventral view; 18 , $\dot{q}$, dorso-lateral view; 19 , 9 , dorsal view. 


\section{Plate ViII-Hemiptera.}

Tibicen septemdecim, $1,8, \sigma^{7}$, ventral views; 3,12 , ᄋ, lateral views; 9 , $\sigma^{7}$, dorsal view; $15, \sigma^{\top}$, lateral view; $18, \%$, dorsal view.

Corixa sp., 2, \&, ventral view; 19 , $\&$, dorsal view.

Benacus griseus, $4,13,14$, + , lateral views; 7 , $q$, ventral view; 6 , $q$, dorsal view. Notonecta undulata, 5, 22, $\sigma^{7}$, lateral views; 10 , 11, dorsal views; $16,17,21$, $\sigma^{7}$, ventral views; 20 , $\%$, ventral view.

\section{Plate IX-Hemiptera.}

Anasa tristis, 1,3 ,, dorsal views; $2,7,8$, $ᄋ$ ventral views; 5 , $\odot$, dorsal and mesal views.

Corixa sp., 4, 6, 10, $\odot$, ventral views; 11,14 , $ᄋ$, dorsal views.

Notonecta undulata, 9 , $\odot$, ventral view.

Benacus griseus, $12,18, \sigma^{7}$, ventral views; $13, \sigma^{7}$. lateral view; $15, \sigma^{7}$, dorsal view; $16, \sigma^{7}$, mesal view; $17, \sigma^{7}$, lateral and ental view.

Notonecta, 19, \&, ventral view.

\section{Plate X-Hemiptera.}

Euschistus variolarius, 1 , ᄋ, dorsal view; 2,6 , ᄋ , ventral view; $3,8, \sigma^{7}$, dorsal views; 9 , ठำ, ventral view; $10, \sigma^{7}$, mesal view.

Anasa tristis, $4,17, \sigma^{7}$, ventral views; $7 . \sigma^{\top 7}$, ental view; $14, \sigma^{\top}$, caudal view; 15 , $\sigma^{7}$, lateral view; $18, \sigma^{7}$, dorsal view; $20, \sigma^{7}$, mesal view.

Notonecta undulata, 5 , ㅇ, dorsal view.

Benacus griseus. 11, \&, caudal view; 12, \&, mesal view; 13, 16, ventral views; 19, or. ventral and ental view.

\section{Plate Xi-Neuroptera, Mecoptera, Trichoptera.}

Corydalis cornuta, $1, \sigma^{7}$, ventral view; $2, \sigma^{7}$, dorsal view; $4, \sigma^{7}$, ventral-caudal view; 5 , + , dorsal view; 6 , + , ventral view; 15 , + , lateral view; 19 , + , caudal view.

Panorpa lugubris, 3, 8, 21, $\sigma^{7}$, lateral views; 9, $\sigma^{7}$, mesal view; 11, \&, ventral view; 12,18 , dorsal views; 14 , $\odot$, ental and ventral views; 16 , $\sigma^{\gamma}$, ventral view; 17 , $\sigma^{7}$, mesal and ventral views;

Nerophilus californicus, $7, \sigma^{7}$, ventral view; $10, \sigma^{7}$, dorsal view; $13, \sigma^{7}$, caudal view.

\section{Plate XII-Coleoptera.}

Harpalus caliginosus, 12,7 ,, , dorsal views; $4,5,8$, ㅇ, ventral views; 9 , $\&$, mesal view; $10, \sigma^{7}$, lateral view; $11,13, \sigma^{7}$, dorsal views; 17,23 . $\sigma^{7}$, ventral views.

Cybister fimbriolatus. $3,18, \sigma^{\nearrow}$, ventral views; $12, \sigma^{\Upsilon}$, mesal view; 14, 21, $\%$, dorsal views; 15 , \&, lateral view; $19, \sigma^{7}$, dorsal view; 20 , $\circ$, ventral view.

Doryphora decemlineata, $6, \sigma^{7}$, ventral view; $16, \uparrow$, ventral view.

\section{Plate XiII-Coleoptera.}

Hydrophilus triangularis, $1,14, \sigma^{\top}$, dorsal views; $6,15,16, \sigma^{7}$, ventral views; 7 ,, , ental view; 11 , ᄋ, ventral view; 20 , ᄋ, dorsal view.

Doryphora decemlineata, $2,13,18, \sigma^{7}$, ventral views; 4,5 , dorsal views; 10,22 , , dorsal views; 17 , $\circ$, ventral view; 24 ,, , ventral and ental views.

Cybister fimbriolatus, 3 , $९$, ental view; 8 , $\sigma^{\top}$, dorsal view; :, $\odot$. dorsal view; 12,21 , $\sigma^{7}$, lateral views; 19 , $\&$, ventral view.

Harpalus caliginosus, 23 , $\odot$, ental view; 25 , + , lateral and ental view. 


\section{Plate XIV-Lepidoptera.}

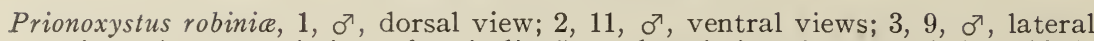
views; $4, \sigma^{7}$, mesal view; of genitalia; 5 , + , dorsal view; 6 , $\%$, ental view of S. 8 ; 8,15 , $\%$, ventral view; $12, \%$, ventral view of 8 th segment; $14,+$, ental and lateral view; 17 , \&, lateral-ental view.

Hepialus humuli, 7 , $\%$, caudal view; $10, \sigma^{7}$, caudal view; 13 , \&, dorsal view; $16,+$, ventral view; $19, \sigma^{7}$, lateral view; 22 , + , lateral view.

Anosia plexippus, 18, ᄋ, lateral view.

Protoparce carolina, 20, ơ , lateral view.

Agrotis ypsilon, 21, + , lateral view.

\section{Plate XV-Lepidoptera.}

A grotis ypsilon, $1, \sigma^{7}$, dorsal view; 6 , ᄋ , dorsal view; $8, \sigma^{7}$, lateral view of genitalia; 11 , o $0^{2}$, ventral view.

Protoparce carolina, 2, ᄋ, dorsal view; 9, $\sigma^{7}$, dorsal view; $12, \sigma^{7}$, ventral view; $14, \sigma^{7}$, lateral view; 15 ,, , ventral view; 16 ,, lateral view.

Anosia plexippus, 3, \&, dorsal view; 4 , $\&$, ventral view; 5,10 , $0^{7}$, ventral views; 7 , $0^{7}$, dorsal view; $13,0^{7}$, lateral view.

\section{Plate XVI-Diptera.}

Calliphora viridescens, 1 , $\sigma^{7}$, dorsal view; $2, \sigma^{7}$, ventral view; $3,7, \sigma^{7}$, lateral views; 4 , 9 , dorsal view; 6 , $ᄋ$, ventral view.

Tabanus sulcifrons, 5,13 , $\sigma^{7}$, ventral views; $8, \sigma^{7}$, detail; $9, \sigma^{7}$, dorsal view; 10 , + , caudal view; 11,15 , $q$, dorsal views; 12,14 , $ᄋ$, ventral views.

Tipula abdominalis, 16, $\odot$, ventral view; 17 , $\odot$, dorsal view; $18,22, \sigma^{x}$, ventral view; 19 , \& , caudal view; $20,21, \sigma^{7}$, dorsal views.

\section{Plate XVII-Hymenoptera.}

Dolerus unicolor, 1 , ㅇ, dorsal view; 5 , ơ , mesal view; 9,19 , $\sigma^{\nearrow}$, dorsal views; 13,15 , $\sigma^{7}$, ventral views; $14,16,20$, $\%$, ventral views.

Vespa maculata, 2,11 , ᄋ, lateral views; $3,4,8,18$, o $\sigma^{7}$, ventral views; 6,17 , ㅇ, dorsal views; $7, \sigma^{7}$, mesal view; 10,21 , + , ventral views; $12,22, \sigma^{7}$, dorsal views. 


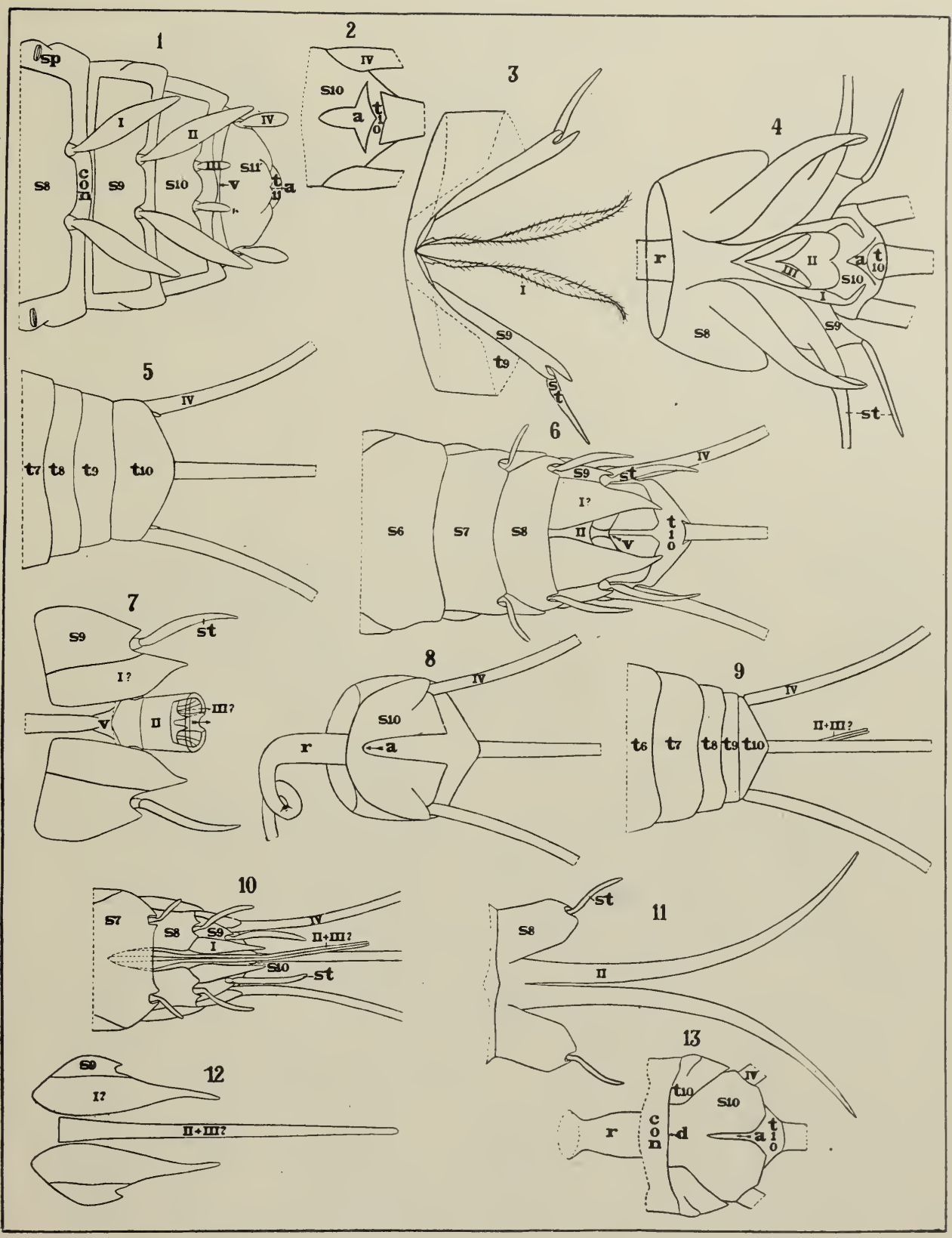

Anna Grace Newell 


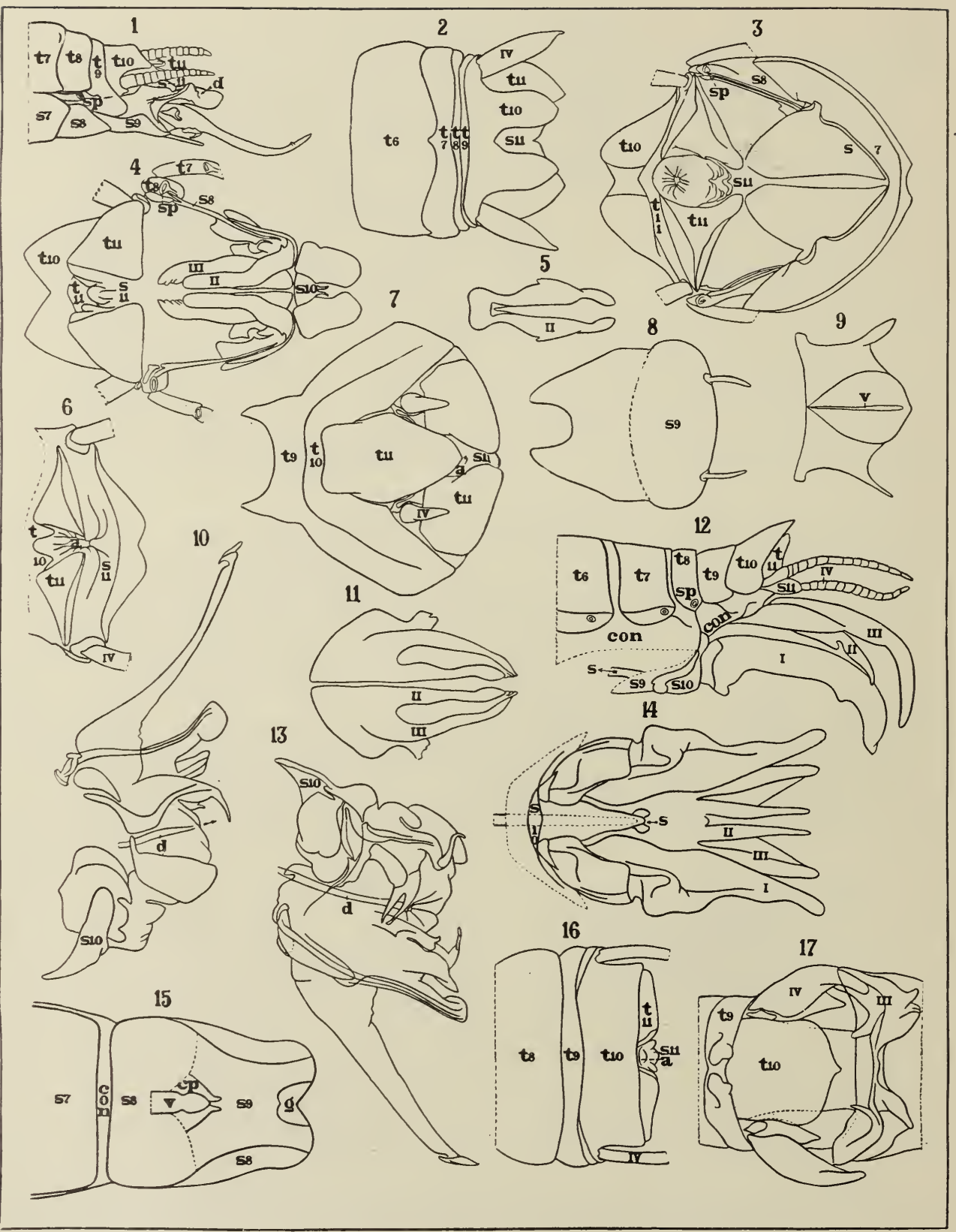




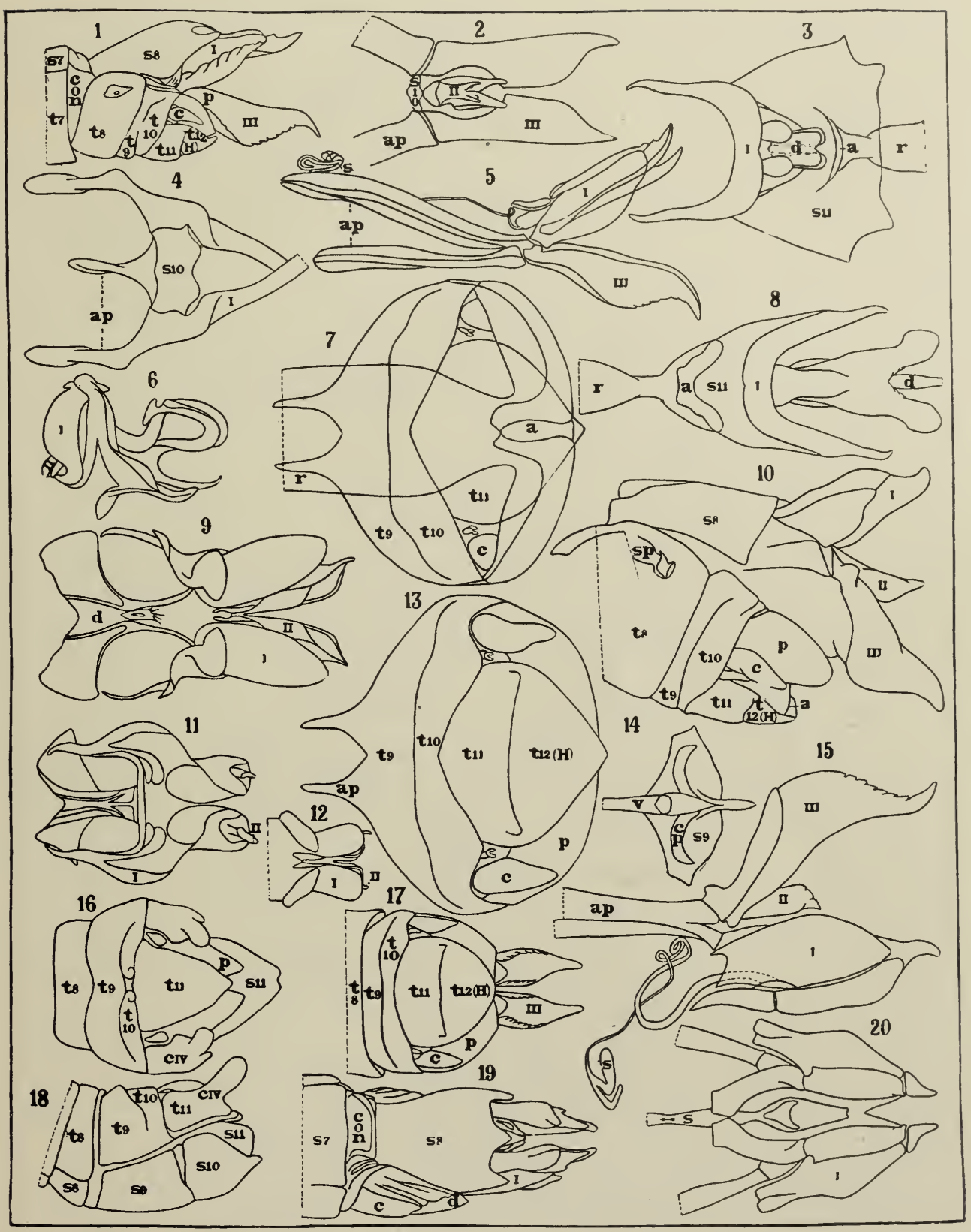

Anno Grace Newell 


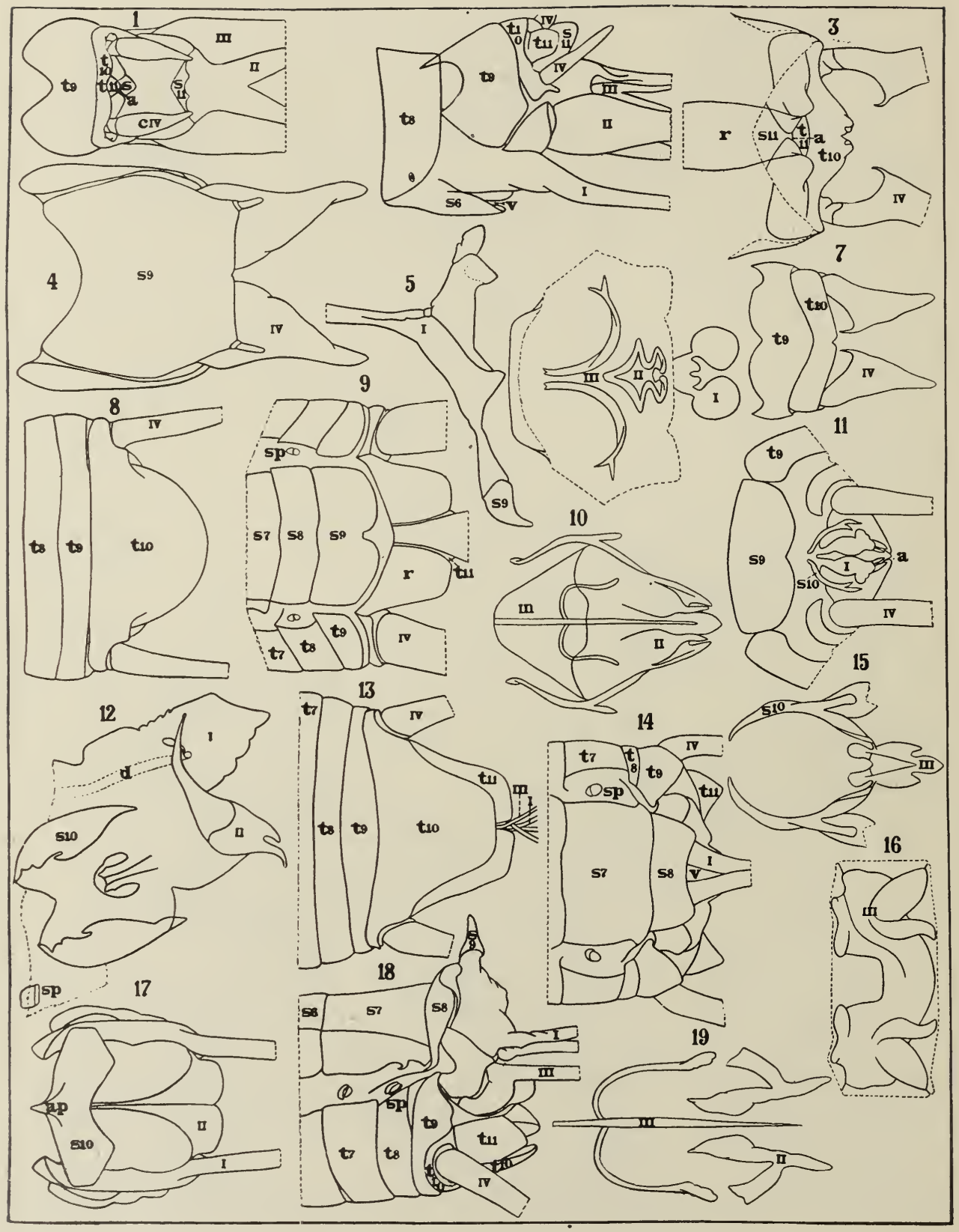




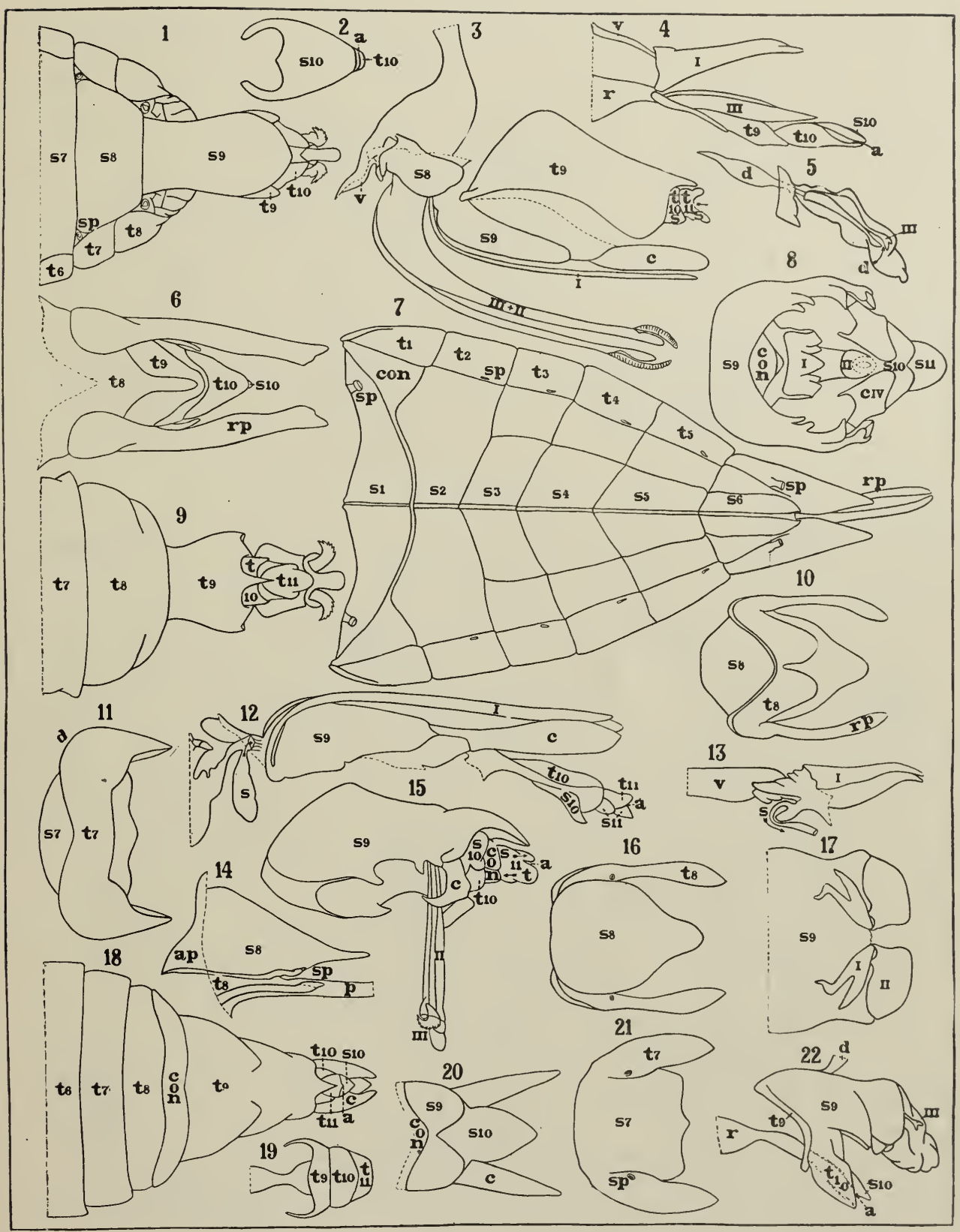




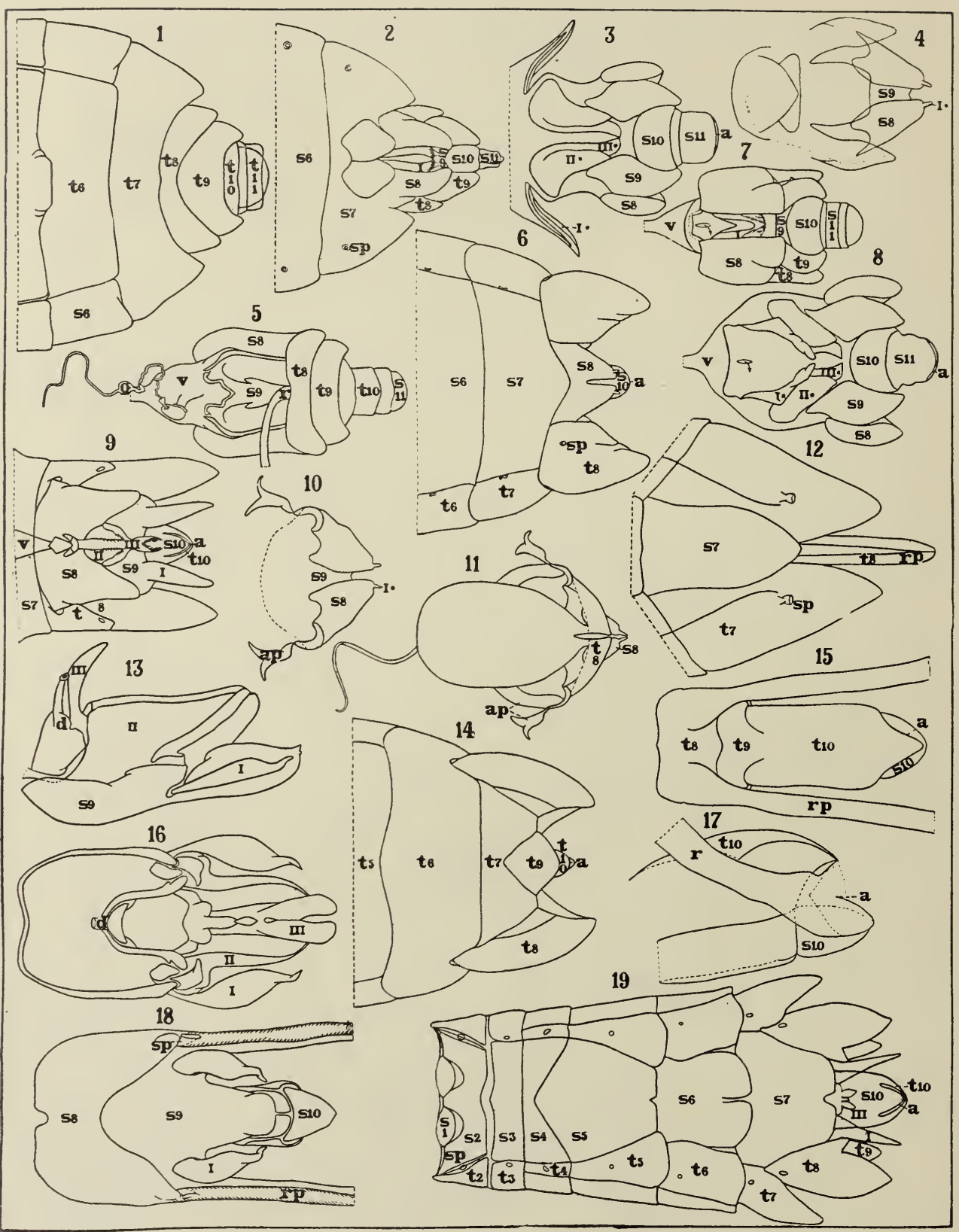




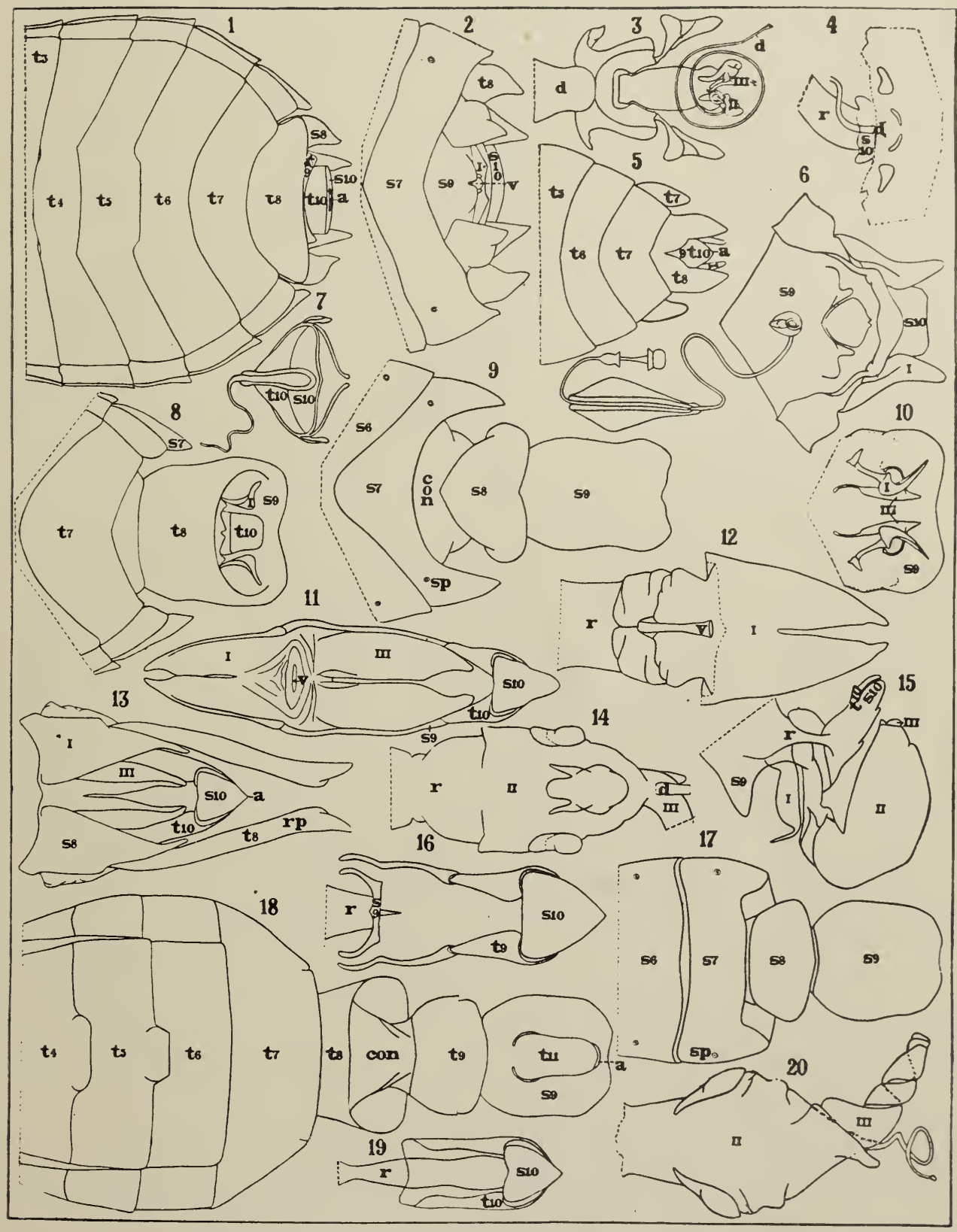

Anna Grace Newell 







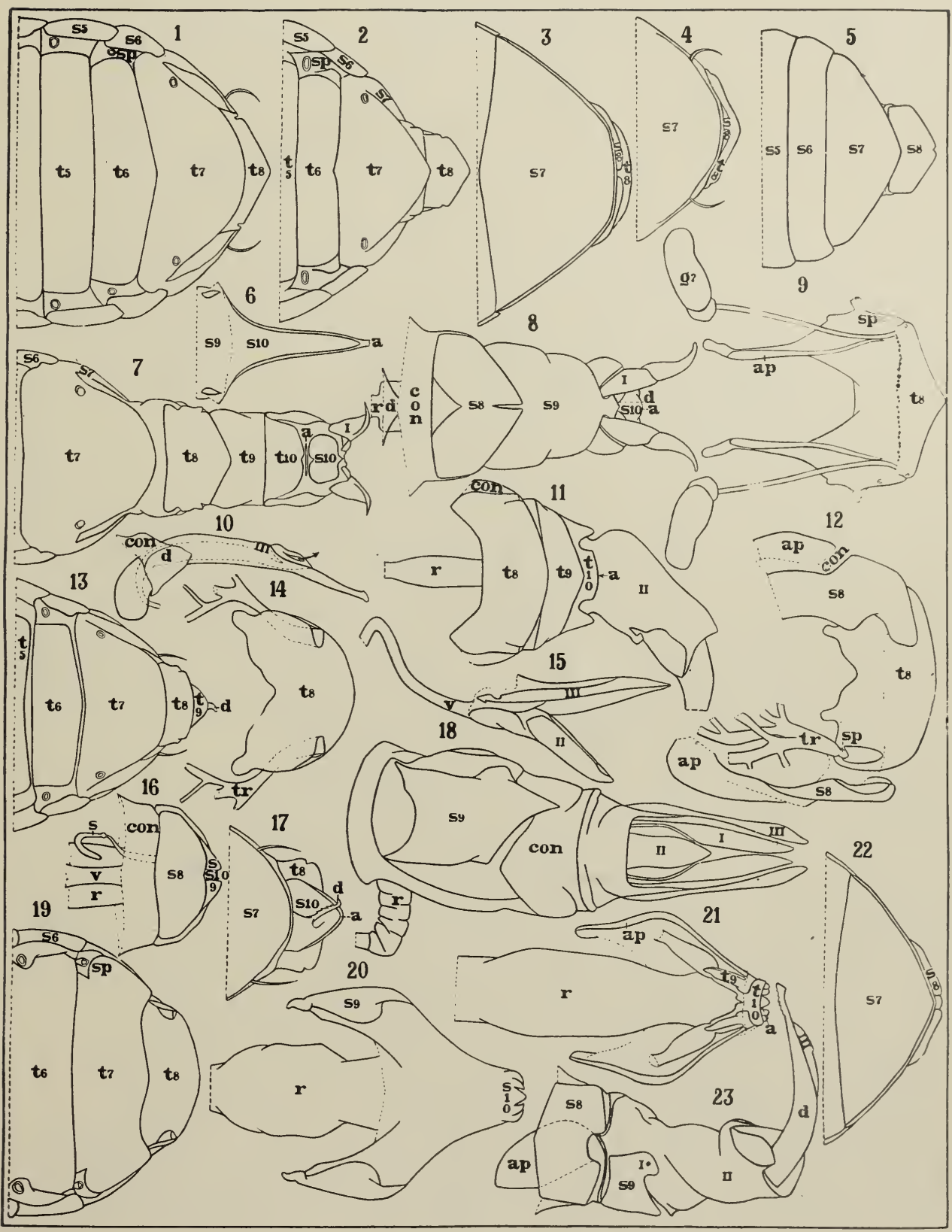

Anna Grace Newell 







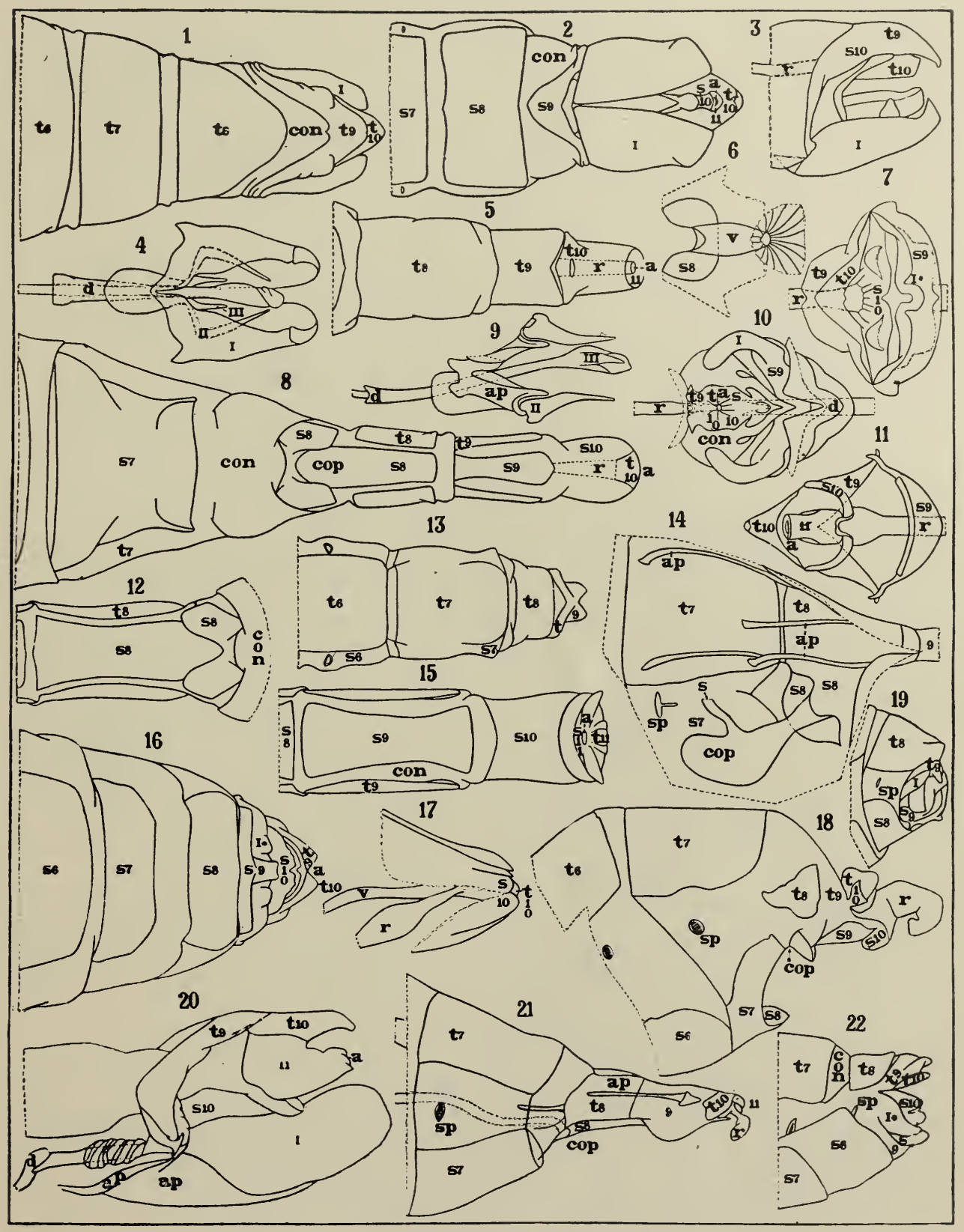

A nno Grace Newell 


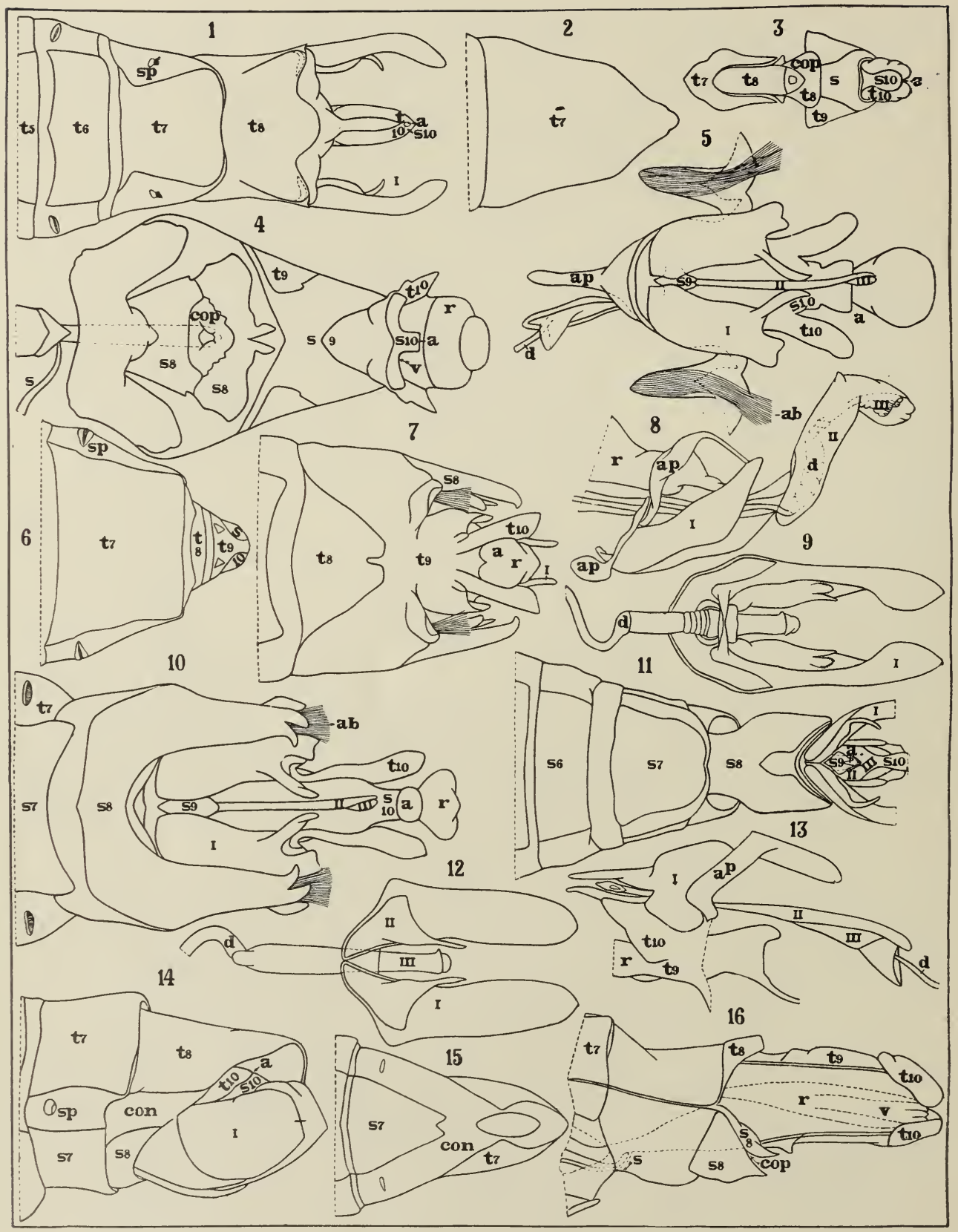




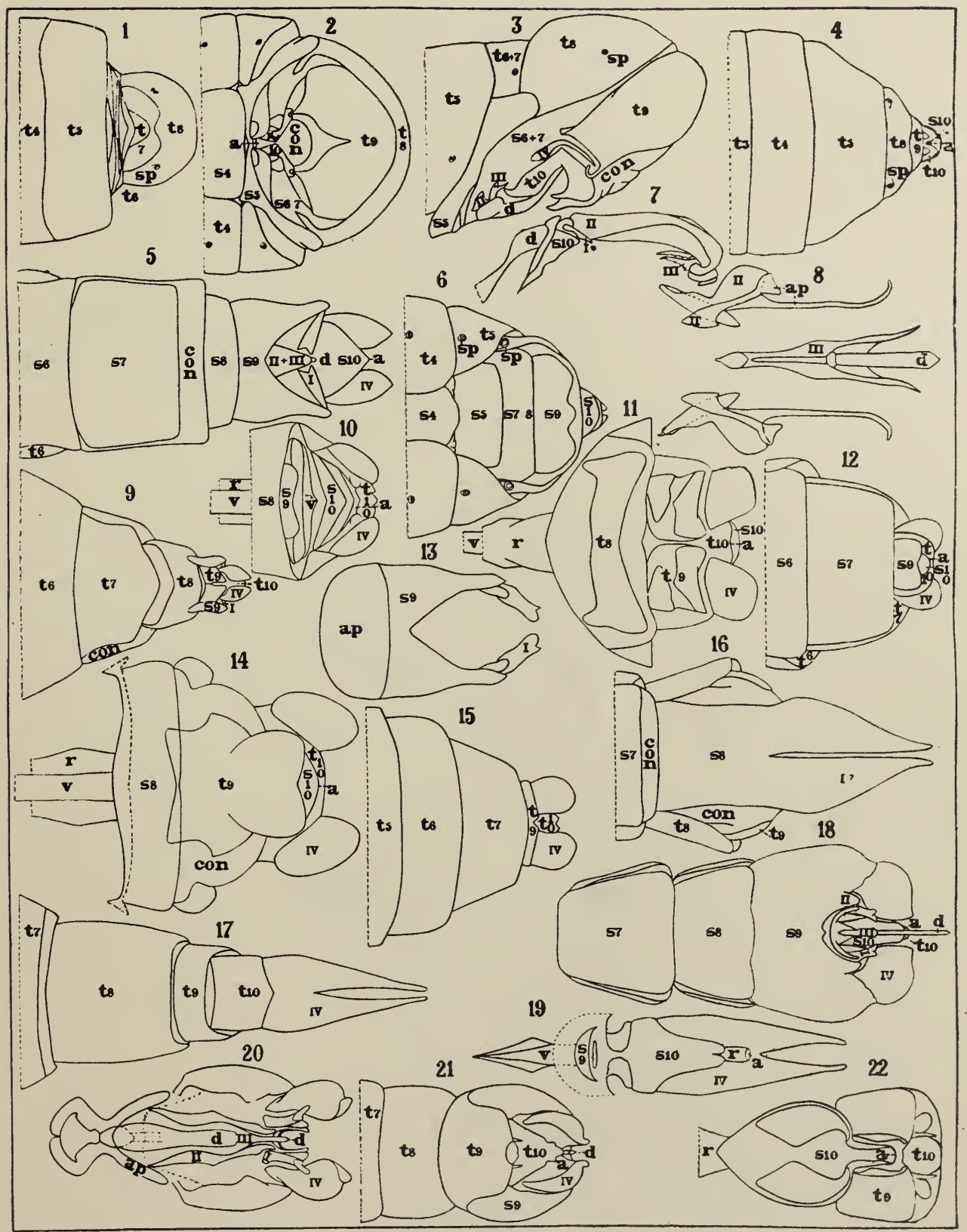

Anna Grace Newell 


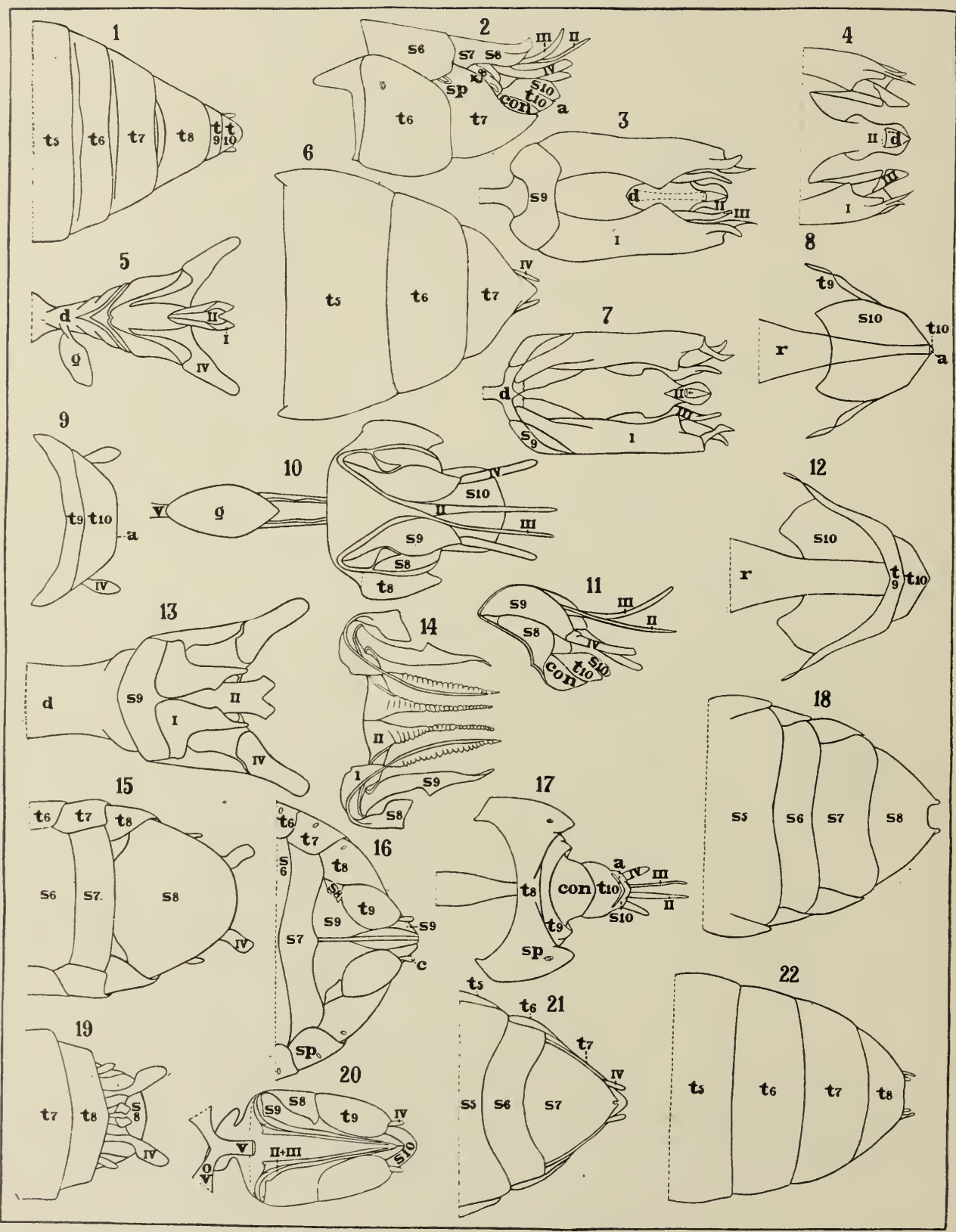



$635-2 y$

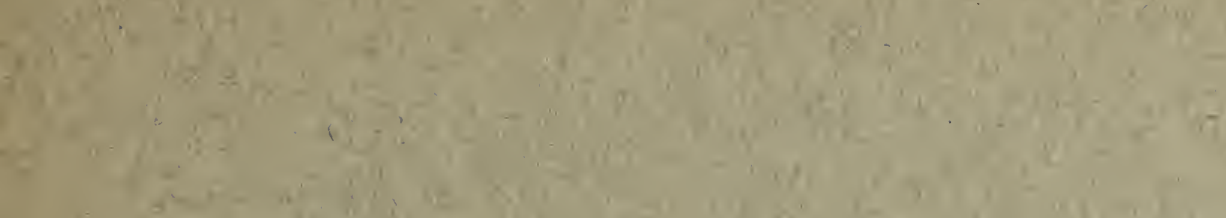

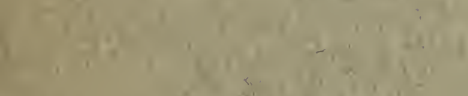

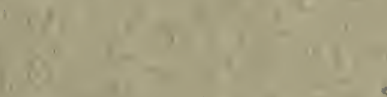

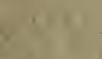

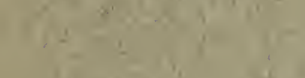

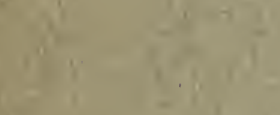

$+\frac{1}{3}$

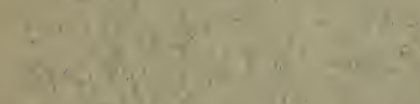

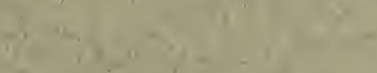

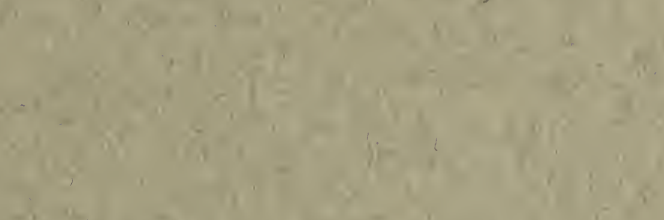

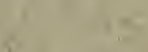

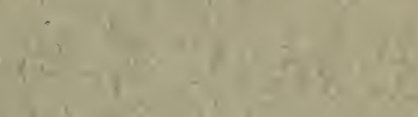

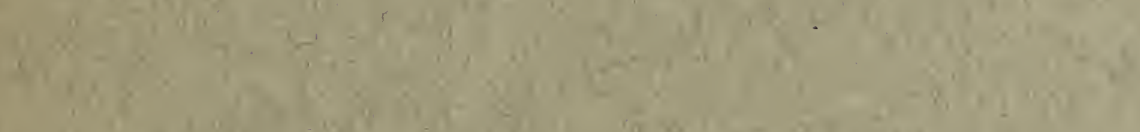

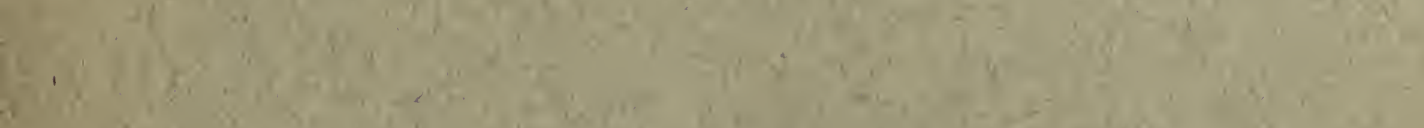

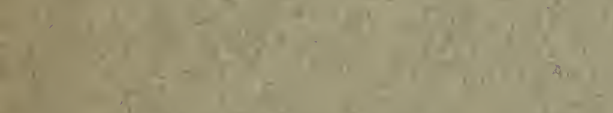

$+\frac{5}{2}+2$

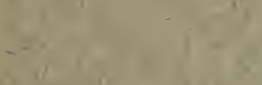

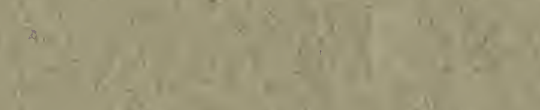

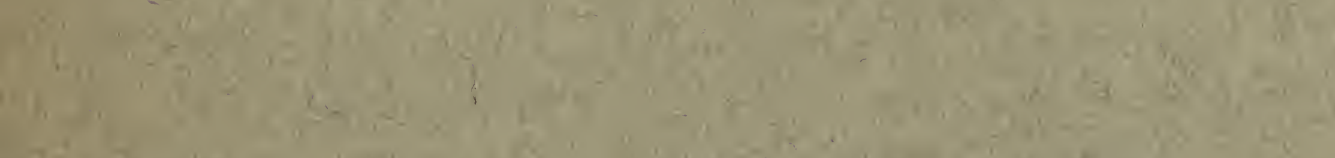

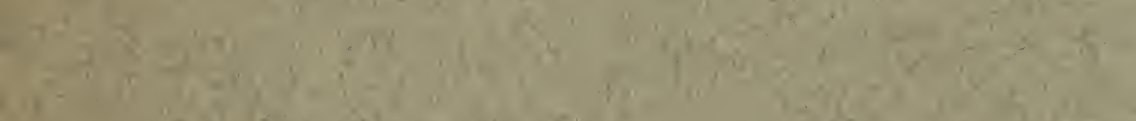

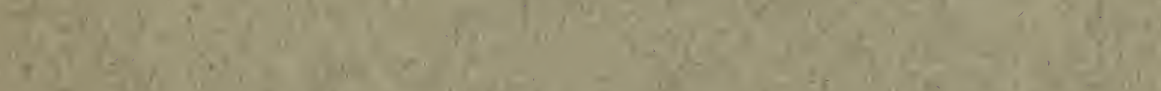

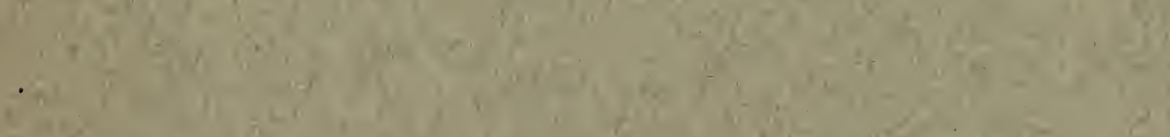

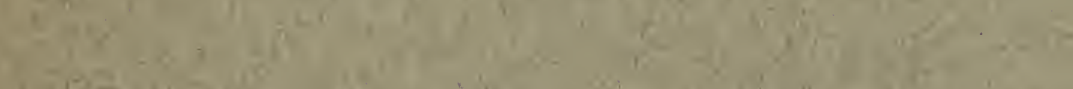

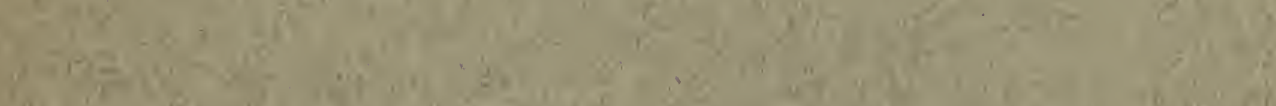

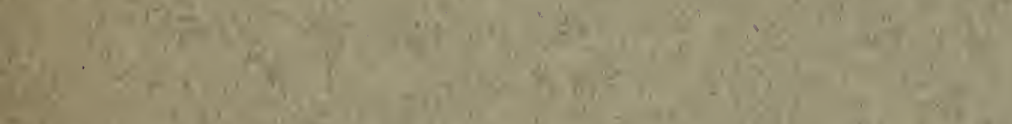

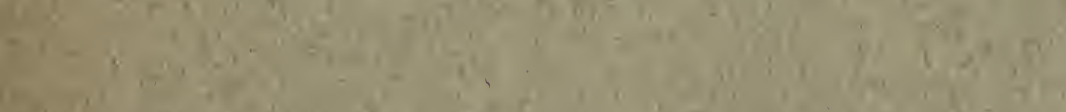

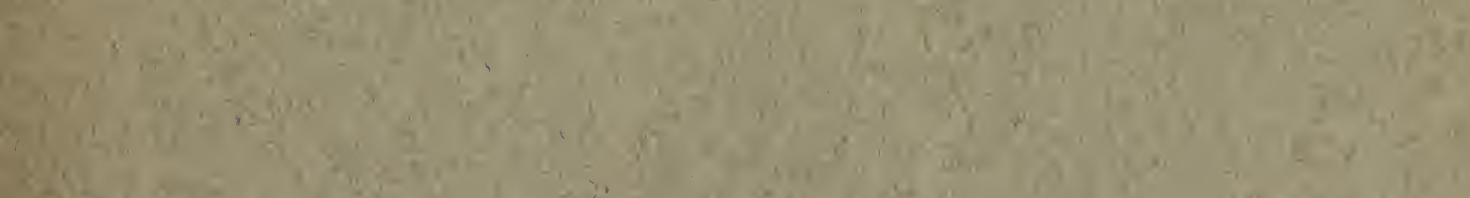
10
0

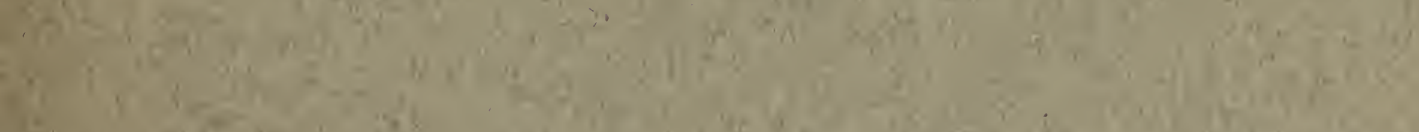

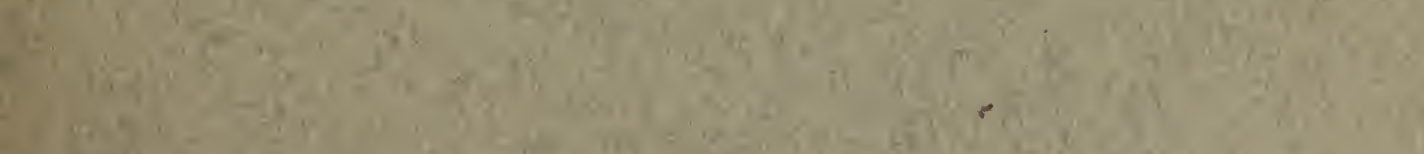




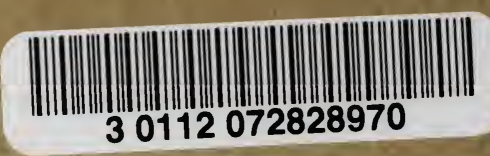

30112072828970 